STATE OF ILLINOIS

DEPARTMENT OF REGISTRATION AND EDUCATION

DIVISION OF THE

NATURAL HISTORY SUR VEY

THEODORE H. FRISON, Chief

\begin{tabular}{lll}
\hline \hline Vol. XX & BULLETIN & Article II \\
\hline
\end{tabular}

\title{
A Survey of the Fishery of the Kaskaskia River
}

WILBUR M. LUCE

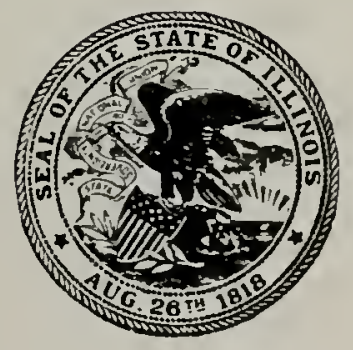

HRINTED BY ALTHORITY OF FIE STATE OF ILLISOIS

URBANA, ILLINOIS

AUGUST, 1933 


\section{STATE OF ILLINOIS \\ DEPARTMENT OF REGISTRATION AND EDUCATION \\ John J. Hallihan, Director}

BOARD OF NATURAL RESOURCES AND CONSERVATION

John J. Hallihan, Chairman

William Trelease, Biology

Henry C. Cowles, Forestry

EDSON S. BASTIN, Geology

William A. NoYes, Chemistry

JoHN W. Alvord, Engineering

Charles M. Thompson, Representing the President of the University of Illinois.

STATE NATURAL HISTORY SURVEY DIVISION

Theodore H. Frison, Chief

Carroll Chouinard, Editor

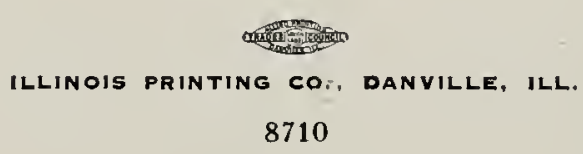





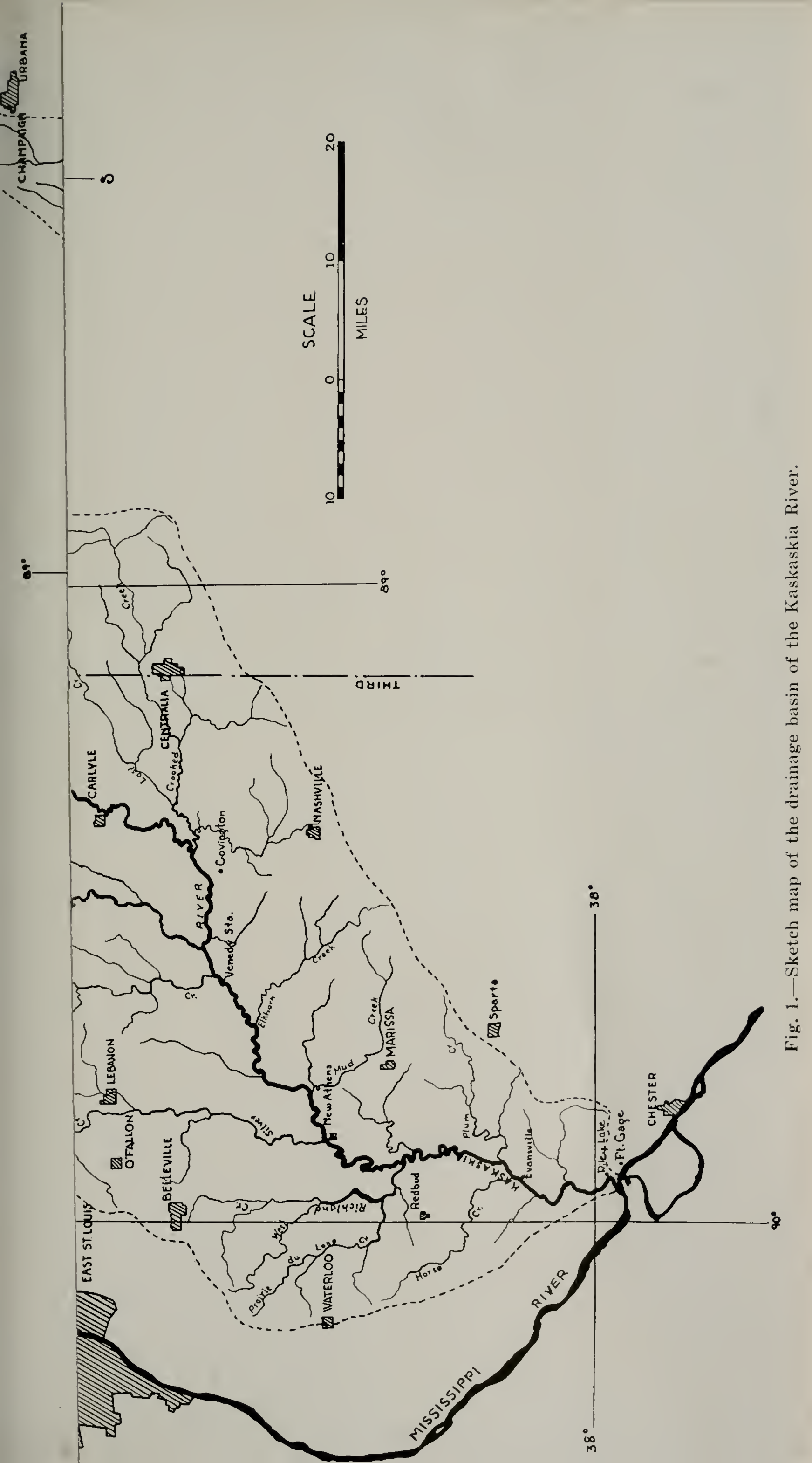





\title{
A Survey of the Fishery of the Kaskaskia River
}

\author{
WILBUR M. LUCE
}

\section{INTRODUCTION}

IN the smaller streams and rivers of Illinois the principal value of the fishes and other aquatic products is attached to hook and line fishing and to the recreation and sport of taking fishes, with secondary importance attending commercial fishing. The Kaskaskia, or Okaw, River ${ }^{1}$ is a fair representative of the secondary streams of Illinois. In this survey we have determined what kinds of fishes are present. A comparison with the collections of fishes made in this stream 30 or more years ago by the late Professor S. A. Forbes and his associates shows that there has been very little alteration in the variety of kinds present.

Statistics gathered by the United States Bureau of Fisheries for 1922 (Sette, 1925) 2 on the commercial fishery of the Kaskaskia present to the hook and line fisherman a very imperfect picture of the kinds and abundances of fishes in this stream. Accordingly, special efforts were made in this survey to collect those kinds which are most attractive to the sportsman, and to form some conception of their sizes and relative abundances, with any additional information readily obtained concerning their life history, growth or other features of their welfare.

An attempt has been made to analyze the effect of some of the more obvious environmental factors and conditions which are known to affect the distribution and abundance of fishes. The Kaskaskia River is one of the cleaner streams of Illinois and there is little reason to believe that pollution has made any extensive inroads on the fish yield. However, at intermittent periods and at certain places, pollutional conditions do exist which either destroy fishes or force them to abandon certain regions, and destroy a large part of their food resources over wide areas.

1. See map facing this page.

2 Leferences are to literature citations, page 121 , following. 
In the course of this survey, 587 of the more important fishes were tagged and rcleased in order to learn whether or not any considerable migrations take place among these useful kinds. While no extremely large migrations have come to our notice from fishes tagged in the Kaskaskia or any other Illinois waters, we were surprised to learn that the catfishes, and in particular the black bullhead, make rather extensive migrations covering distances 10,20 or even 40 miles upstream within a few days or

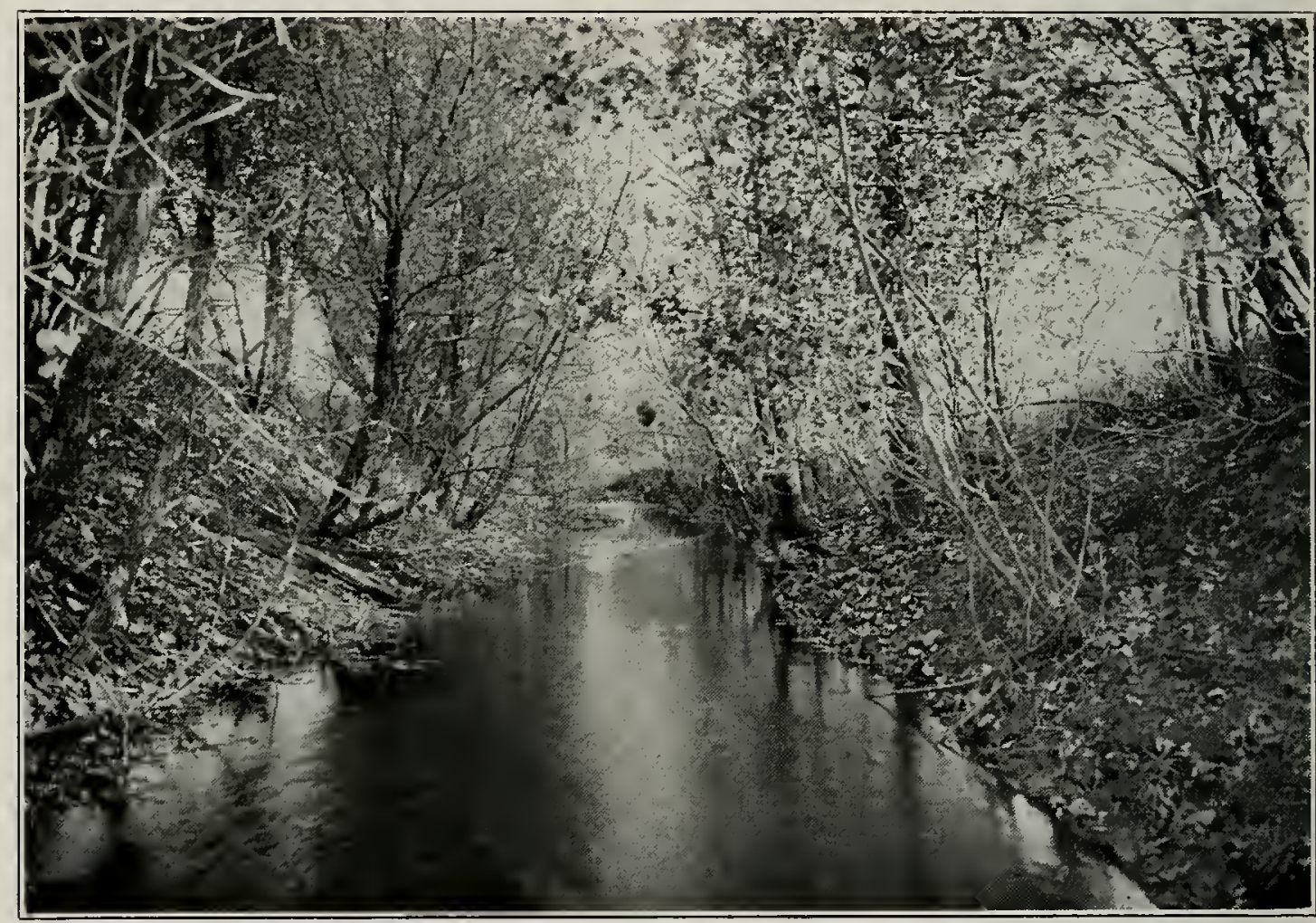

Fig. 2.-Kaskaskia River near Bondville, October, 1929.

weeks. Migrations of a similar order but somewhat smaller have been found to prevail among others of our more common fishes either in the Kaskaskia or in other waters of the state. This fact leads us to believe that following such catastrophes as pollution, extreme drouth or other conditions which may drive the fishes out of wide areas, the reëstablishment of suitable conditions is followed by rapid recovery. Within a year sufficient: breeding stock will have entered the area as migrants and within two or three years the fish population will have assumed its normal aspects. This is of considerable consequence as a practical matter of conservation since it shows that restocking of our waters by such natural means goes on rapidly and under ordinary conditions makes artificial propagation and distribution of fishes in these waters unnecessary. No evidence has come to light in this survey which indicates that the fish population of the Kaskaskia is in any sense seriously depleted, that the river is overfished, or that any of the ordinary popular remedies will be reflected by increases in fish yield. 
At various times in the past decade or two considerable portions of the Kaskaskia have been open to commercial fishing. At present the entire river is closed and fishes may be taken legally only with hook and line. Indeed, it seems that the Kaskaskia as a whole is most useful as a place in which to fish with hook and line, except for the lowermost part of its course from Evansville to the mouth in Randolph county. There the stream has a width and depth not found in its upper reaches and fishes trpical of the main channel of the Mississippi are found in great numbers.

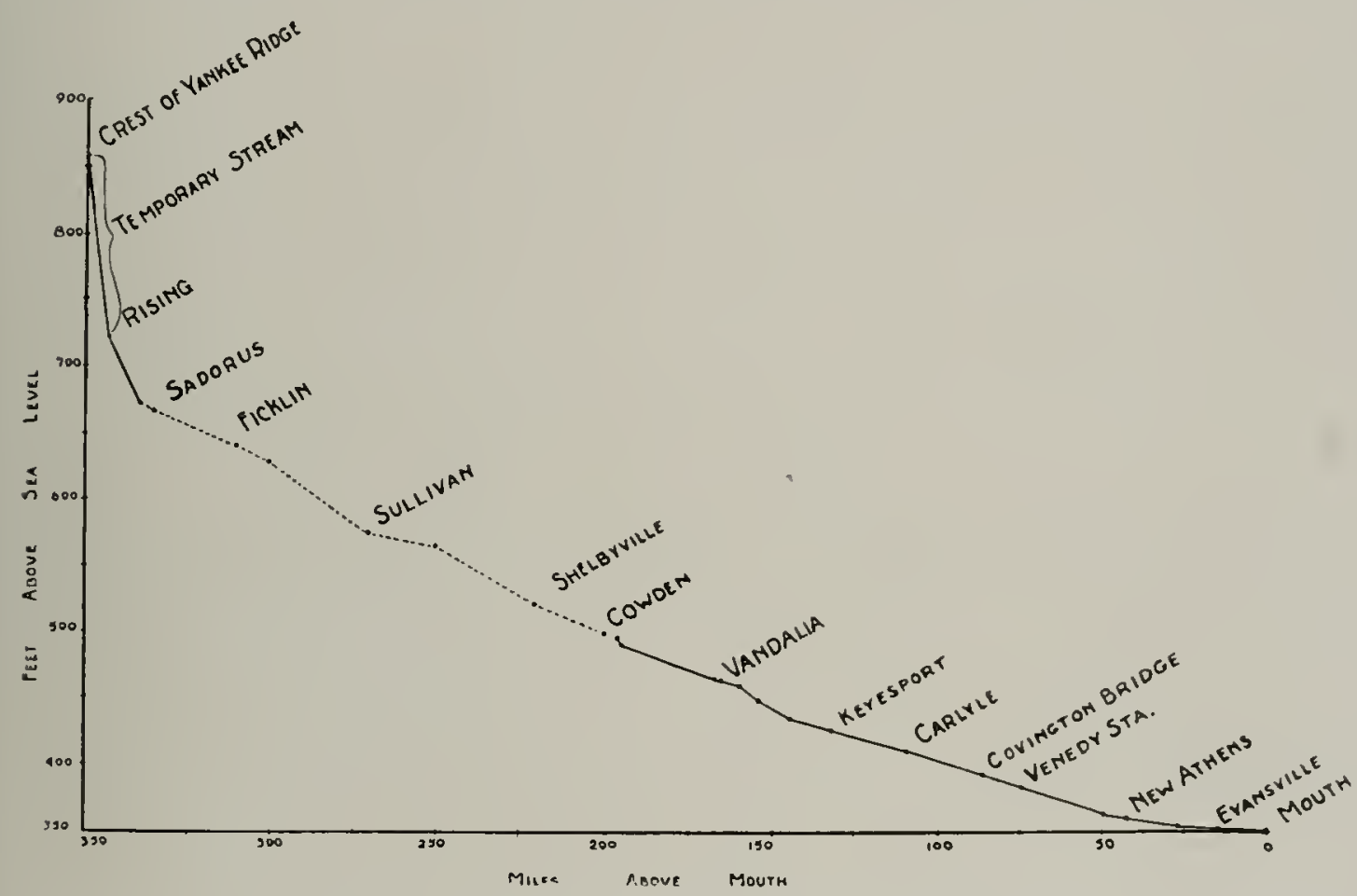

Fig. 3.-Profile of the Kaskaskia River.

Spoonbill cat, channel cat, bullheads, the huge flathead cat and Fulton cat are numerous, together with still greater numbers of carp and buffalo. All of these are commercial fishes and are seldom or irregularly taken on hook and line. It is commonly known that many commercial fishes of the Mississippi River proper retreat into the mouth of the Kaskaskia during the winter months and move out again in spring.

In this paper the fishes of the Kaskaskia have been taken up one by one and in the case of the larger and better known kinds points of interest and usefulness have been discussed, while the smaller, rarer and less important kinds are only mentioned. In the course of this survey quantitative collections were made of the small bottom animals which are the most important constituents of the food of all kinds of larger fishes. Detailed analyses of this material and data will be presented in a later report. Material was also collected for determining the rate of growth of all the more important kinds of fishes, but this, too, can be presented more 
effectively when material from other parts of the state is brought into comparison. It may be mentioned here that such a study of the rate of growth of the white crappie is being completed. Comparison of the total lengths in inches of white crappies for different ages in the Kaskaskia and Sangamon rivers is shown in the following tabulation.

White Crappie

\begin{tabular}{|c|c|c|c|c|}
\hline \multirow{2}{*}{ River } & \multicolumn{4}{|c|}{ Average Length in Inches at } \\
\hline & $1 \mathrm{yr}$. & 2 yrs. & 3 yrs. & 4 yrs. \\
\hline Kaskaskia. & 3.2 & 5.2 & 6.2 & 6.7 \\
\hline Sangamon. & 3.2 & 5.3 & 5.8 & 6.4 \\
\hline
\end{tabular}

\section{HYDROGRAPHY}

THE Kaskaskia River has its source on the southwestern slope of Yankee Ridge in Champaign county, about 2 miles northeast of the town of Rising, 6 miles northwest of Champaign-Urbana and about 40 miles west of the Indiana state line. The ravine which forms the source extends down the slope of a hill, the top of which is the highest point in Champaign county, 860 feet above sea level.

The river flows in a general southwest direction, diagonally across the state, and empties into the Mississippi River about 7 miles above the town of Chester in Randolph county. Elevation at the mouth is about 350 feet above mean sea level when the Mississippi is at an ordinary stage of water. The straight line distance from source to mouth is 180 miles, but the river is very crooked throughout the greater part of its course, except for the upper 20 miles which have been dredged and straightened. Its actual length is more than 350 miles. The width of the river is $40-60$ feet in Moultrie country, 120-150 feet in Clinton and Washington counties, 150-250 feet in St. Clair county and 250-500 feet in Randolph county.

As one would expect from the winding character of its channel, the river has a slight fall throughout most of its length. On the profile shown in Fig. 3, data for the elevations from Cowden to the mouth were taken from maps based on a survey made in 1908 by the United States Department of Agriculture in coöperation with the Illinois State Geologicai Survey and the United States Geological Survey, data for elevations from the source to the edge of the Mahomet quadrangle just above Sadorus were taken from the contour elevations of that quadrangle, and those for 
that part of the profile represented by dotted lines were calculated from the railroad elevations on the base map of Illinois prepared by the Illinois State Geological Survey in coöperation with the United States Geological Survey. If we consider the top of Yankee Ridge as our starting point, the stream drops 140 feet during the first 2 miles of its course. Where it leaves the Mahomet quadrangle, at a point about 12 miles from its source, its elevation is about 670 feet-a fall of about 190 feet from the highest point in the headwaters. From this point to the mouth of the river the fall

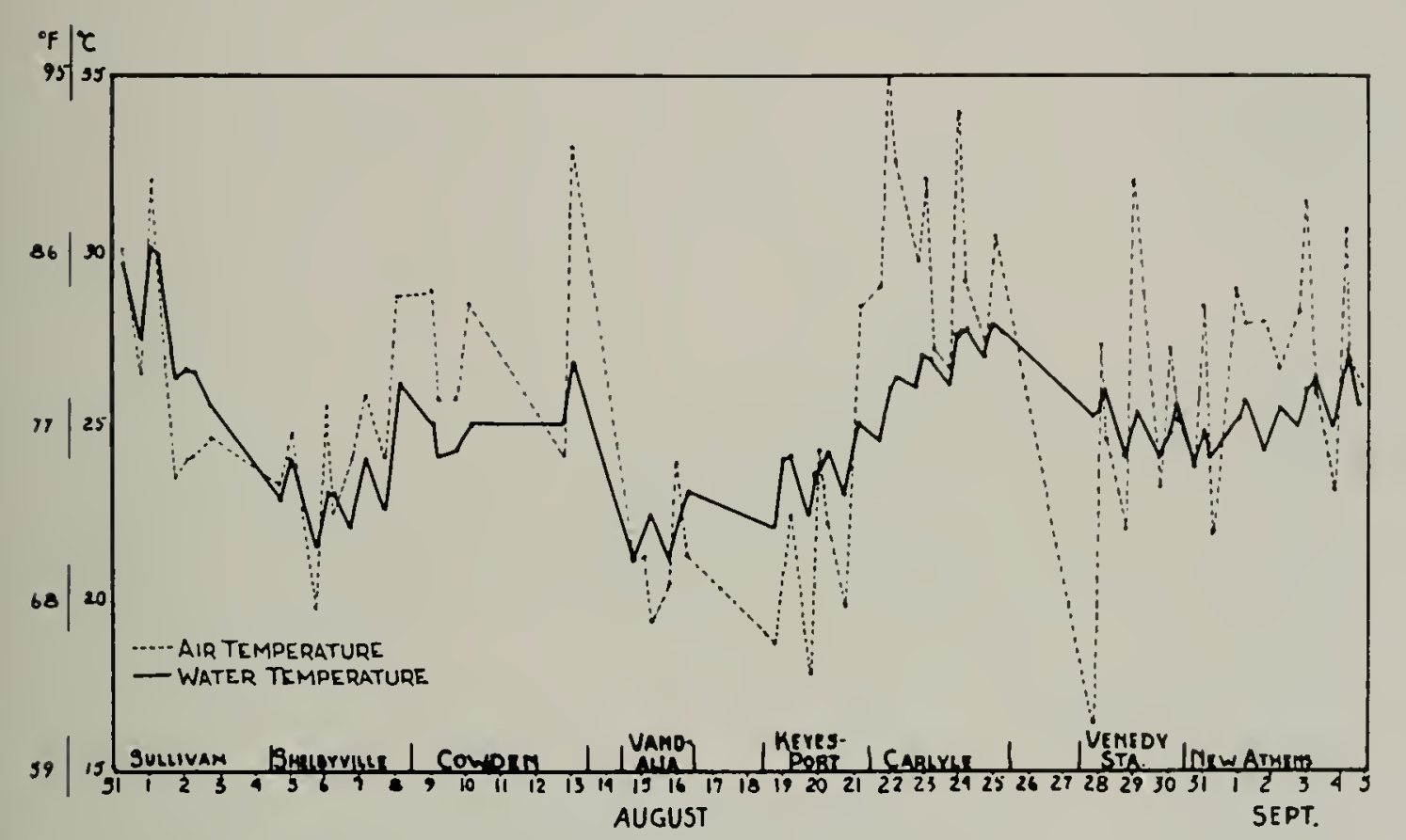

Fig. 4.-Air and water temperatures on the Kaskaskia in the summer of 1929 .

is much less, varying from a maximum of 55 feet in 18 miles through Moultrie county to the low gradient found in St. Clair county where the fall is only 10 feet in 20 miles.

As a result of the stream's very low gradient and winding character. its rate of flow is quite slow after emerging from the Shelbyville moraine. Above Shelbyville, at least during periods of comparatively low water. there are stretches of quiet pools and riffles alternating with comparatively swift water, but below this point the stretches of rapid water occur less often and the stream has a slower and more nearly uniform flow.

The graphs in Fig. + show the temperatures recorded while the field party was working on the Kaskaskia during the summer of 1929. The water temperatures were taken about 2 inches below the surface, well out in the channel of the river. The air temperatures were taken in the shade. The same thermometer was used for both. As one would expect, the graphs show that there is less variation in the water than in the air. 'Thus the water ranged from $69.8^{\circ}$ to $86^{\circ} \mathrm{F}$. while the air ranged from $61^{\circ}$ to 
$95^{\circ} \mathrm{F}$. The general trend is the same in both, and variations in the water are always in the same direction as, and doubtless a direct result of, variations in the air.

The water of the river is usually quite turbid, thercolor of the suspended matter depending upon the nature of the soil. Above Shelbyville, where the river is draining the darker soils of the Wisconsin glaciation, the water is grayish brown when turbid; below this point, where drainage is from Illinoisan glaciation, the color is brownish yellow.

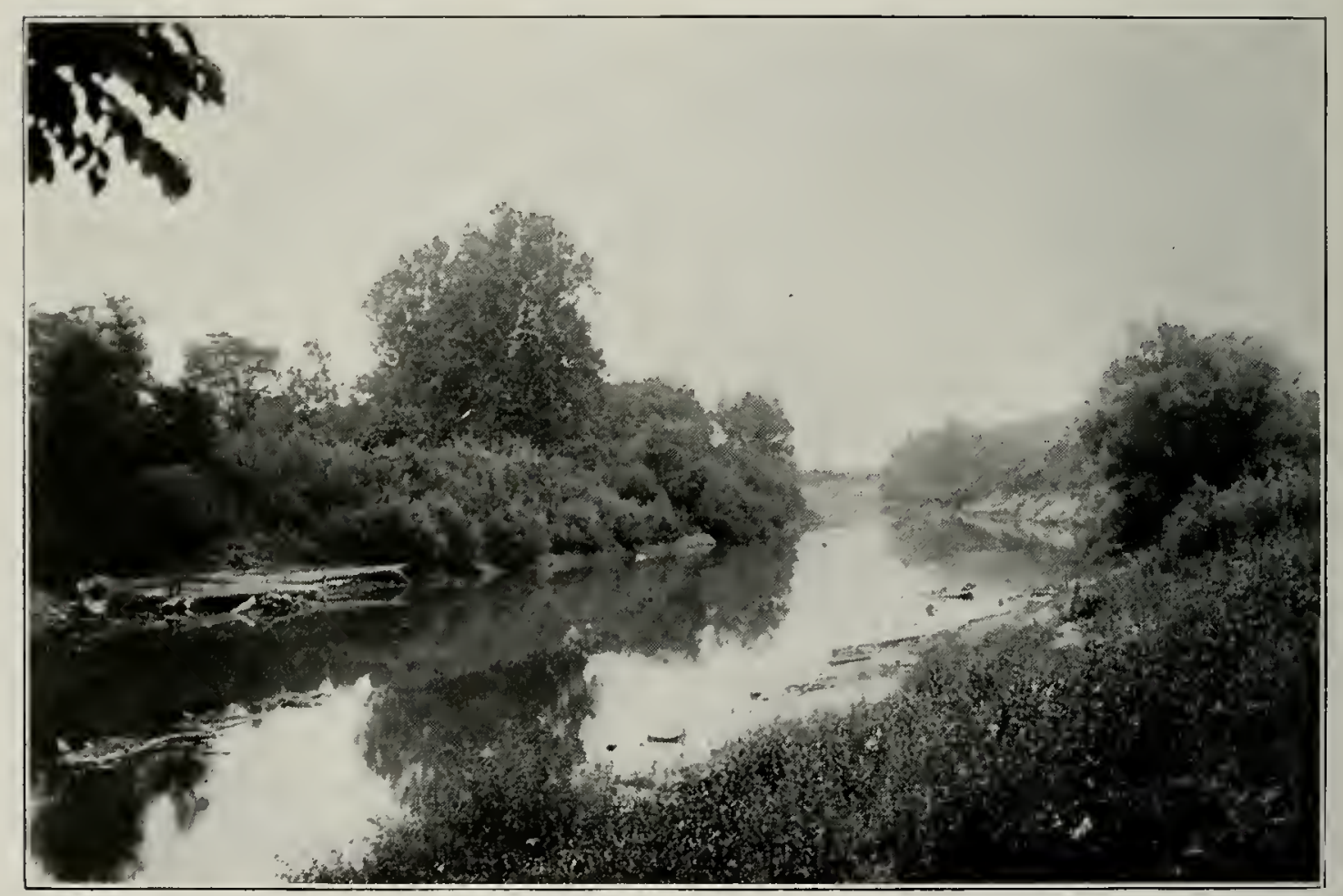

Fig. 5.-Kaskaskia River at Vandalia, July, 1930.

The bottom of the river is not worn down to bedrock except for about 20 miles near Shelbyville, where the bed is limestone. Throughout the first 10 miles from its source the stream has been dredged and the bottom is muddy, with little sand and gravel and with considerable aquatic vegetation. For the rest of the river's length the bottom is primarily sand and gravel with very little mud, and is almost devoid of aquatic and shoreline vegetation. Wherever riffles occur in Douglas, Coles, Moultrie and Shelby counties, the bottom is composed of coarse pebbles and glacial boulders of various sizes. Through St. Clair and Randolph counties during periods of low water the bottom is often covered with a layer of fine silt as much as a foot deep, which overlays a bed of hard packed sand and gravel and which is frequently scoured away during periods of flood.

In Champaign and Douglas counties the river has developed no extensive valley, and its bed is not much lower than the surrounding plain. 
Through Moultrie and Shelby counties the valley varies in width from $1 / 8$ mile to $11 / 2$ miles, the topography being rather rough throughout this region. Where the river emerges from the Shelbyville moraine its valley widens to about 3 miles. This width is maintained as far as New Athens in St. Clair county, except at Carlyle in Clinton county where the valley narrows to about 1 mile for a short distance. From New Athens to the mouth the valley has an average width of 1 mile.

Table I.-Monthly Discharge of the Kaskaskia River at Vandalia. Drainage Area 1,980 Square Miles.

\begin{tabular}{|c|c|c|c|c|c|c|c|}
\hline \multirow[b]{2}{*}{$I_{E A R}$} & \multirow[b]{2}{*}{$\begin{array}{l}\text { MONTH OF } \\
\text { MaXiMUM }\end{array}$} & \multirow[b]{2}{*}{$\begin{array}{l}\text { Month of } \\
\text { MinimuM }\end{array}$} & \multicolumn{4}{|c|}{ Discharge in SECOND-FEeT } & \multirow[b]{2}{*}{$\begin{array}{l}\text { RUN-OFF } \\
\text { IN INCHES }\end{array}$} \\
\hline & & & Max. & Min. & Mean & $\begin{array}{c}\text { Per } \\
\text { square } \\
\text { mile }\end{array}$ & \\
\hline 1908 & May & Sept. & 7,720 & 12 & $\ldots$ & $\ldots$ & $\ldots$ \\
\hline 1909 & Apr. & Jan. & 7,570 & 29 & 1.650 & .834 & 11.25 \\
\hline 1910 & Mar. & Nov. & 6,970 & 59 & 1,240 & .626 & 8.52 \\
\hline 1911 & Oct. & Aug. & 13,000 & 3.5 & 1,740 & .879 & 11.96 \\
\hline 1912 & Mar. & $\left\{\begin{array}{l}\text { Nov. } \\
\text { Dec. }\end{array}\right\}$ & 7,210 & 62 & & & $\cdots$ \\
\hline 1913 & & Gage 2 & 1.7 feet 1 & arch 29 & 913 & & \\
\hline 1915 & May & Oct. & 14,800 & 43 & 1,390 & .702 & 9.53 \\
\hline 1916 & Jan. & Sept. & 14,400 & 19 & 1,340 & .677 & 9.20 \\
\hline 1917 & June & $\left.\begin{array}{l}\text { Oct } . \\
\text { Nov. }\end{array}\right\}$ & 11.100 & 19 & 1,000 & .505 & 6.88 \\
\hline 1918 & May & Oct. & 8,460 & 38 & 1,150 & .581 & 7.92 \\
\hline 1919 & Mar. & Sept. & 11,000 & 37 & 1,350 & .682 & 9.28 \\
\hline 1920 & May & Oct. & 12,200 & 36 & 1,790 & .904 & 12.31 \\
\hline 1921 & Sept. & $\left.\begin{array}{l}\text { Oct. } \\
\text { Nov. }\end{array}\right\}$ & 2,920 & 43 & \multicolumn{3}{|c|}{ New bridge put in } \\
\hline 1922 & Apr. & Sept. & 18,800 & 19 & 2,300 & 1.16 & 15.72 \\
\hline 1923 & Mar. & Oct. & 13,700 & 18 & 870 & .439 & 5.94 \\
\hline 1924 & Dec. & Aug. & 10,500 & 78 & 1,680 & .848 & 11.59 \\
\hline 1925 & Mar. & Sept. & 9,500 & 35 & 960 & .485 & 6.95 \\
\hline 1926 & Sept. & Oct. & 8,460 & 37 & 1.220 & .616 & 8.36 \\
\hline
\end{tabular}

The drainage basin of the Kaskaskia, or Okaw, is long and narrow, extending northeast to southwest for 180 miles, with an average width of 30 miles, a maximum width of 55 miles and an area of 5,670 square miles. The upper third lies in the Wisconsin glacial drift and the lower two-thirds in the Illinoisan.

Most of that part of the basin which is made up of the WVisconsin glacial till is drained by tiles, the soils here consisting predominantly of brown silt loam and black clay loam, with a rather loosely packed subsoil 
that makes tile laying economically possible. Artificial drainage increases the rapidity of the run-off. In the greater part of the basin, which consists of Illinoisan and earlier drifts, the soil is made up of loams, silts and loess. Here the subsoil is a compact clay, which condition also results in a very quick run-off. Consequently the river is subject to large and rapid varia-

Table II.-Monthly Discharge of the Kaskaskia River at New Athens. Drainage Area 5,220 Square Miles.

\begin{tabular}{|c|c|c|c|c|c|c|c|}
\hline \multirow{2}{*}{ YEAR } & \multirow{2}{*}{$\begin{array}{l}\text { Month of } \\
\text { Maximum }\end{array}$} & \multirow{2}{*}{$\begin{array}{c}\text { Month of } \\
\text { Minimum }\end{array}$} & \multicolumn{4}{|c|}{ Discharge in Second-feEt } & \multirow{2}{*}{$\begin{array}{l}\text { Run-OFF } \\
\text { IN INCHES }\end{array}$} \\
\hline & & & Max. & Min. & Mean & $\begin{array}{l}\text { Per } \\
\text { square } \\
\text { mile }\end{array}$ & \\
\hline 1907 & Jan. & Oct. & 20,300 & 663 & 5,160 & .989 & 13.52 \\
\hline 1908 & May & Nov. & 31,700 & 264 & 7,380 & 1.41 & 19.20 \\
\hline 1909 & Apr. & Jan. & 17,800 & 450 & 5,830 & 1.12 & 15.07 \\
\hline 1910 & Mar. & Nov. & 27,000 & 344 & 4,590 & .879 & 11.93 \\
\hline 1911 & May & Aug. & 25,500 & 162 & 4,180 & .801 & 10.87 \\
\hline 1912 & Apr. & Dec. & 37,200 & 198 & $\ldots \ldots$ & $\ldots$ & $\ldots$ \\
\hline 1913 & & Gage 32 & 9 feet $M$ & rch 30 & 913 & & \\
\hline 1915 & Aug. & Oct. & 63,100 & 133 & 6,020 & 1.15 & 15.64 \\
\hline 1916 & Feb. & Sept. & 54,800 & 185 & 5,310 & 1.02 & 13.83 \\
\hline 1917 & June & Oct. & 26,100 & 142 & 2,900 & .556 & 7.55 \\
\hline 1918 & Apr. & Nov. & 20,300 & 107 & 2,790 & .534 & 7.29 \\
\hline 1919 & Mar. & Sept. & 12,700 & 162 & 2,930 & .561 & 7.62 \\
\hline 1920 & Nov. & Oct. & 28,000 & 175 & 5,030 & .964 & 13.09 \\
\hline 1921 & Apr. & Nov. & 13,300 & 130 & 1,700 & .326 & 4.39 \\
\hline
\end{tabular}

tions in level and volume of water discharged. These differences are indicated in Tables I and II, showing the discharge in cubic feet per second at Vandalia and New Athens as compiled by the United States Geological Survey.

The bottomlands of the river valley are in general 10 to 20 feet above the usual stage of water. The banks of the river, which are usually steep, are muddy as far downstream as Sullivan, below which they become more sandy. In spite of the high banks of the river the valley is subject to serious floods from time to time, and for this reason the bottomlands of the lower Kaskaskia are not cultivated extensively except in Fayette county near Vandalia. Even in this area the drainage of the bottomlands has not been very successful and much of the land is still in timber.

During the summer of 1929 the mouth of the river was filled with a delta of soft mud, so that water coming out of the Kaskaskia was distributed among numerous wide shallow channels which were difficult if not impos- 
sible of passage, even by rowboat. In the spring of 1930 a flood washed out this muddy delta.

The floodplain of the Kaskaskia, after the river has emerged from the Shelbyville moraine, is dotted with small overflow lakes and sloughs. These are especially numerous through Bond, Clinton, Washington and St. Clair counties. None of them are extensive in area and their total combined area is not large.

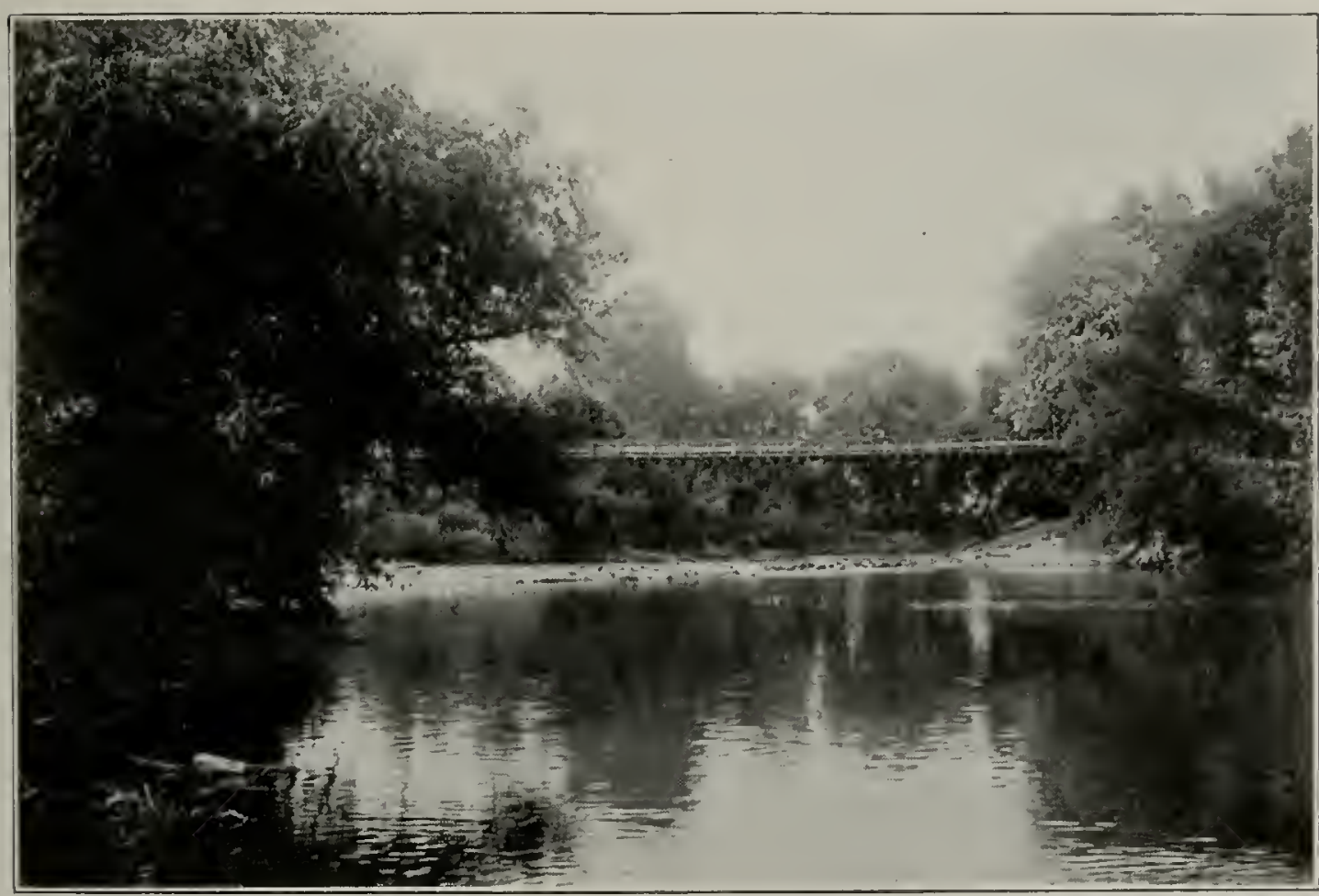

Fig. 6.-Kaskaskia River at Carlyle, July, 1930.

In the lower Kaskaskia basin there are numerous ponds on the surrounding high lands. Individually, these are usually less than an acre in extent but many are permanent, as they contained water throughout the very dry summer of 1930 .

The main tributaries of the Kaskaskia are Richland, Silver and Shoal creeks to the westward, and Crooked Creek to the eastward. Other than these, there are numerous smaller tributary creeks, Fig. 1.

Perhaps one of the most interesting facts in connection with the hydrography of the Kaskaskia is the stealing of the lower part of the Kaskaskia valley by the Mississippi. The old mouth of the Kaskaskia was near the town of Chester, at the southern end of what is now Kaskaskia Island, about 7 miles below the present mouth of the river. On April 18, 1881, the Mississippi broke through the neck of land at the bend 2 miles above the old town of Kaskaskia. There was at this point a difference of 8 feet in the level of the two rivers, the Kaskaskia being the lower. The result was that the diverted water of the Mississippi soon cut a channel into the Kaskaskia 
and appropriated the lower 7 miles of its bed. This new channel was originally but 500 to 600 feet wide, so that at first it carried only a small part of the volume of the Mississippi. Gradually the new channel became widened and deepened until finally the old channel filied up, and at times of low water it is now possible to walk dry-shod from Missouri to Kaskaskia Island. Since the east bank of the Kaskaskia consists of the limestone cliffs that form the bluffs of the Mississippi valley, in widening the new channel the river cut away the softer alluvial west bank and approached the site of the historic town of Kaskaskia. This town had been settled about the year 1700 and had played an important part in the early history of Illinois, as it was the first capital of the state. The town was not destroyed immediately, but the Mississippi in widening its new channel cut away the soil so that Kaskaskia's buildings and improvements gradually disappeared in the bed of the river during the years 1886-1909. Only a small corner of the original town site now remains.

\section{PERSONNEL}

FIELD work on the Kaskaskia was done mainly during the summers of 1928 and 1929 and early in the spring of 1930. During the summer of 1928 Dr. David H. Thompson and Mr. Francis D. Hunt made a study of the headwaters of the Kaskaskia as part of the field work for a report on the fishes of Champaign county. During the summer of 1929 Dr. Willard F. Stanley and the writer conducted field studies on the Kaskaskia from Sullivan to the mouth of the river. In the early spring of $1930 \mathrm{Mr}$. Hunt made further field observations near the mouth of the river. Occasional observations were made at various points during the summer of 1930 by several staff inembers. Identification of the minnow collections was made by Mr. Hunt and checked by Mr. R. E. Richardson. The plankton identifications and estimates were made by Dr. Samuel Eddy. The entire project has been under the close supervision of Dr. Thompson and any value which it may have is largely due to his guidance. The study was begun under the general supervision of the late Professor S. A. Forbes, formerly chief of the STate Natural History Survey, and has been continued under Dr. T. H. Frison, his successor.

\section{METHODS AND EQUIPMENT}

THE general plan of the field work in the summer of 1929 was to make collections and observations at intervals of 10 to 20 miles throughout the course of the river. Temporary headquarters were established for periods of three to five days at each of the following places: Sullivan, Shelbyville, Cowden, Vandalia, Keyesport, Carlyle, Venedy Station, New Athens and Reilly Lake. 
For transportation the field party used a half-ton truck with a trailer carrying a 16-foot flat-bottomed skiff. Where depth of the water allowed, an outboard motor was used to propel the boat, but elsewhere oars were used because the stage of water was so low and there were so many bars and snags in the river that the outboard motor was of little use. The field party carried the following equipment: a canvas tent, $6 \times 8$ feet; three 30 inch, 1 -inch-mesh hoop nets with 5-foot wings; a "common sense" minnow

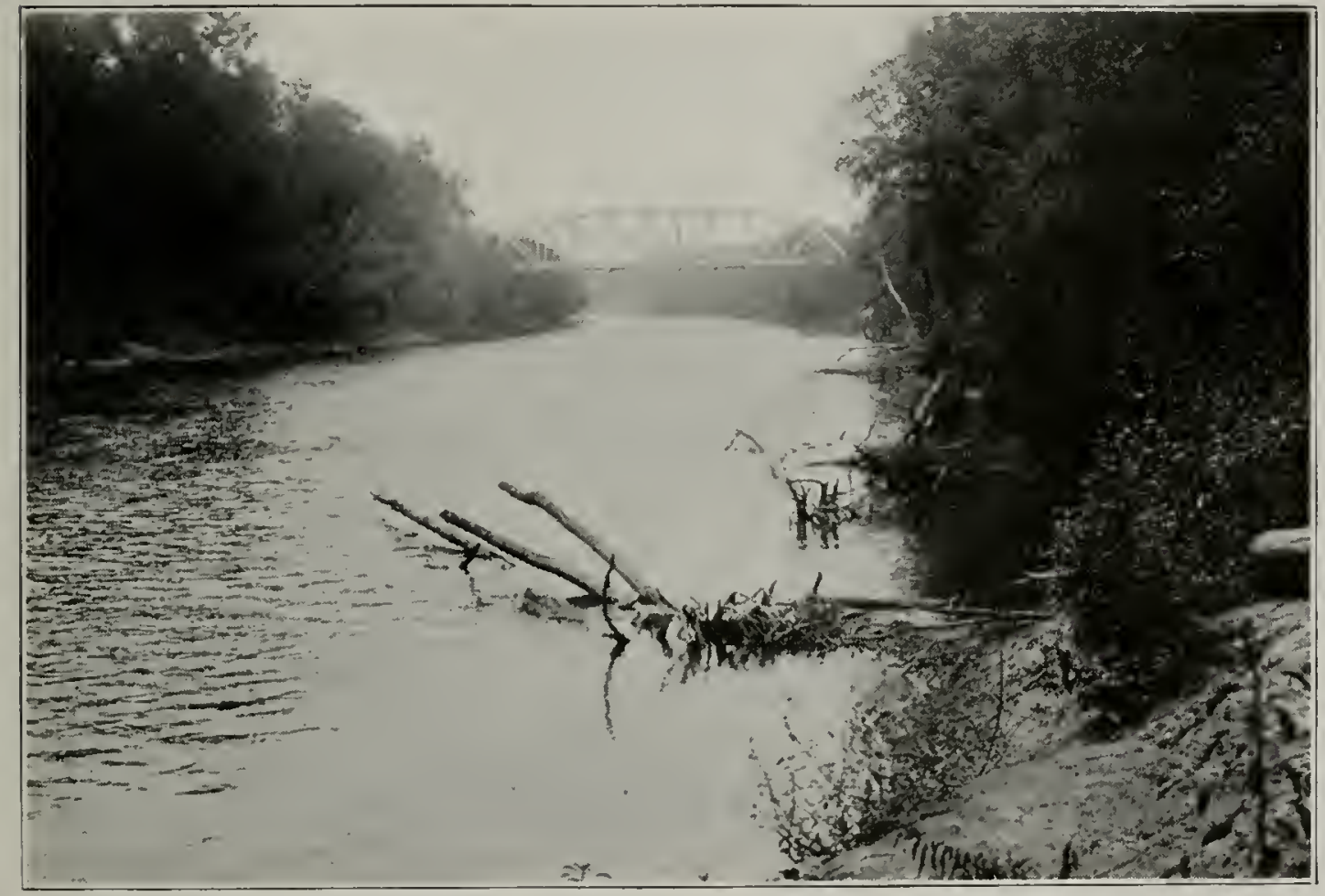

Fig. 7.-Kaskaskia River at New Athens, July, 1930.

seine, $1 / 6$-inch mesh, $4 \times 12$ feet; a 1 -inch-mesh trammel net, $6 \times 75$ feet; a bottom-sampling outfit consisting of a Peterson dredge, a circular sieve (12 inches in diameter, with t0 meshes to the inch) and a water-tight wooden box (20 inches square and 3 inches deep); a 1t-quart galvanized iron pail; a galvanized iron washtub; a plankton-sampling outfit consisting of a piece of No. 20 silk bolting cloth, a 1-liter dipper and a glass funnel; an aquatic dip net with 5-foot handle; two 250-foot trot-lines with 100 snells and $3 / 0$ hooks; a thermometer in a wooden case; a dairy balance with dial graduated to tenths of a pound; a fish measuring board attached to the balance; Monel metal fish tags, sizes 2 and 3 , each bearing a serial number on one side and the initials INHS on the other; tongs for affixing the tags; a supply of bottles and jars of assorted sizes, together with labels, alcohol and formalin; and a leather notebook filled with $5 \times 8$-inch cards bearing serial accession numbers.

The general procedure of work at each place was as follows. As soon 
as a suitable place was found on the river bank, the equipment was unloaded, the tent pitched, the boat launched and the hoop nets set in likely situations, since the main object was to catch as many fishes as possible. Temperature of water and air were taken and recorded three times daily. The hoop nets were raised twice daily and the fishes removed from them into a tub of water and taken to the bank where the weighing and measuring apparatus was set up. Each kind of fish, its length from tip of snout to base of caudal fin and its weight to the nearest twentieth of a pound were recorded in the notebook, together with length of time the net had been set, date and description of environmental conditions. About ten scales were taken from the left side between the lateral line and the dorsal fin of each of the scaled fishes and were placed in a small manila envelope. On the outside of the envelope were recorded the notebook accession number, the tag number, the name of the stream, the location, date, kind of fish, its length and weight. The fish was then tagged near the base of the caudal fin, on the dorsal edge, and returned to the stream. The catching, measuring and tagging of the fishes taken in the hoop nets consumed the greater part of the time at each stop along the river. A record was also kept of turtles and other animals in the hoop nets.

Since certain kinds of fishes avoid small-meshed hoop nets, other methods were also employed. A trammel net was occasionally dragged as a seine, or set and the fishes driven into it. On account of the number of snags and other obstructions in the Kaskaskia, its use as a seine was not satisfactory, few fishes being caught. Trot-lines were also set across stream, with about 50 hooks to the line. Crayfish, minnows or soaked corn were used for bait. The trot-lines were quite satisfactory for catching carp, which avoid hoop nets of small mesh during periods of clear water. Some catfish were also caught by this method. Samples of small fishes were taken with a minnow seine, dragged over an estimated area of 15 square yards to each haul. The entire sample was killed in formalin, transferred to a cheesecloth sack, labeled and stored in a keg of formalin. Identification of the minnows was made later in the laboratory.

Samples of the bottom fauna were taken in as many different kinds of bottom as could be found in each vicinity. A Petersen dredge was used for taking samples in mud, gravel and sand bottoms. Where the bottom consisted of pebbles or rocks and the dredge could not be used, the organisms were rinsed and picked off the rocks by hand. The samples were preserved and sent to the laboratory for identification.

A plankton sample was taken at each stop along the river by straining 20 liters of water from midstream through No. 20 silk bolting cloth. These collections were preserved in 80 per cent alcohol and examined later in the laboratory. 
A sample of the fresh-water musscls was taken at each place visited. These usually were taken by hand, as all other methods were found to be unsatisfactory, and the shells were preserved and taken to the laboratory for identification.

\section{THE VALUE OF THE FISHERY}

PRINCIPAL sources of information on the fishery of the Kaskaskia, or Okaw, River are the survey made by Forbes and Richardson for "The Fishes of Illinois," published in 1909; a local survey near Charleston, Illinois, made by Hankinson (1913) ; statistics compiled by the United States Bureau of Fisheries (Sette, 1925); and a detailed study of the distribution and abundance of fishes in Champaign county (Thompson and Hunt 1930). The first two of these sources show the kinds of fishes found in the Kaskaskia and give notes on their habitat relationships, life cycles and general abundance, but afford little information for a comparison with other streams of the state from the standpoint of fish yield. The statistics of the United States Bureau of Fisheries show the value of the commercial fishery supported by each stream system. The latest statistics, those for the year 1922 , indicate in a general way the relative importance of the main rivers of the state as follows.

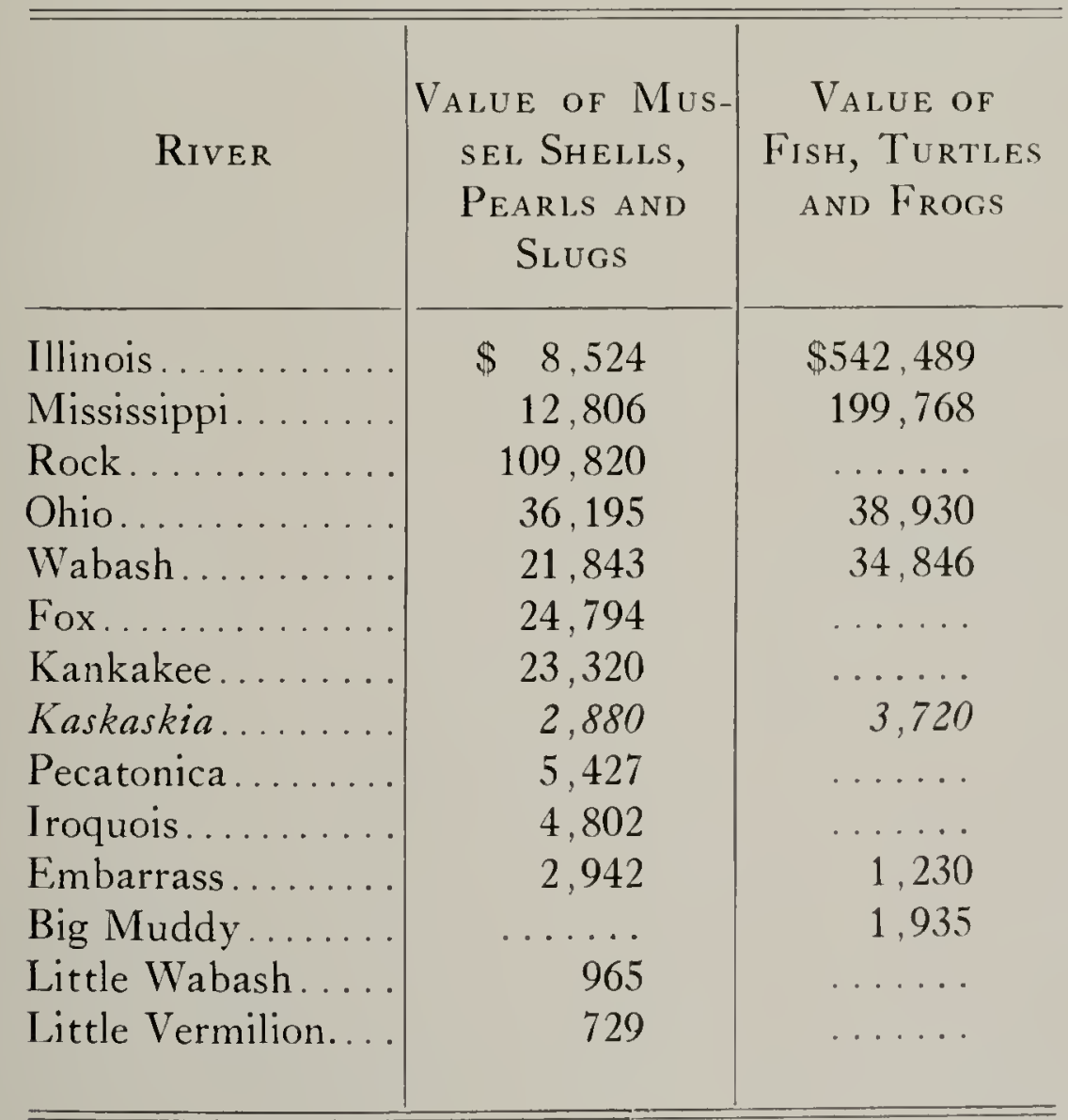


According to this criterion the Kaskaskia ranks eighth among the rivers of the state.

At the time this census was taken commercial fishing in the Kaskaskia basin was limited to the main channel from Covington bridge to the mouth. This includes the course of the stream across Randolph, St. Clair, and about one-half of Washington, counties. Up to 1915 the entire river was open to commercial fishing. The history of its status since that time is outlined in the following records obtained from the office of the State Department of Conservation.

Record of Fish Preserve Orders Issued in Connection
with the Kaskaskia River.

Jan. 14, 1915 Kaskaskia River and tributaries made a fish preserve.

Apr. 12, 1916 Kaskaskia River opened to commercial fishing from Carlyle to confluence with the Mississippi (but all tributaries remain closed).

May 31, 1921 Kaskaskia River and tributaries from Carlyle to Covington bridge made a fish preserve.

Sept. 15, 1927 Kaskaskia River and tributaries opened to commercial fishing in Fayette, Moultrie and Shelby counties.

June 5, 1928 Main channel of Kaskaskia River opened to net fishing, from the point where said river crosses the dividing line between Fayette and Clinton counties, south and southwest to the Covington bridge between Clinton and Washington counties,-all tributaries in said section of the river to remain preserves.

Oct. 1, 1930 Kaskaskia River and all tributaries made a fish preserve:

As shown in Table III, the bulk of the catch of fish in 1922 was carp and buffalo, together totalling 16,800 pounds and valued at $\$ 1,835$. Catfish and bullheads, weighing together 7,300 pounds, were valued at $\$ 1,2+5$. The drum, or sheepshead, contributed 5,200 pounds, worth $\$ 640$. Mussel shells and pearls, however, almost equalled fish in money value, comprising 43.6 per cent of the total commercial fishery in that year.

Perhaps a greater asset of the Kaskaskia consists of those intangible benefits accruing to health and enjoyment which result from use of the stream as a place of recreation. Throughout most of its length the river is large enough to afford ample opportunity for boating and swimming as well as angling. Numbers of fishing clubs have camps along the middle 
reaches of the stream. These camps are especially numerous on the floodbottom lakes in Clinton, Washington and St. Clair counties, but the river is visited at other points also by many people.

At the time this survey was being made on the Kaskaskia the Natural History Survey was also carrying on a similar survey of the Sangamon River. Since the same methods of study were used in both systems, we

Table III.-The Commercial Fishery of the Kaskaskia River for 1922.*

\begin{tabular}{|c|c|c|c|c|c|c|c|c|c|}
\hline \multirow{3}{*}{ PRODUCT } & \multicolumn{6}{|c|}{ TACKLE } & \multirow{2}{*}{\multicolumn{2}{|c|}{ Total }} & \multirow{3}{*}{$\begin{array}{c}\text { Per- } \\
\text { CEnt- } \\
\text { AGE }\end{array}$} \\
\hline & \multicolumn{2}{|c|}{ Fyke nets } & \multicolumn{2}{|c|}{ Hand lines } & \multicolumn{2}{|c|}{ Dredges, etc. } & & & \\
\hline & Pounds & Dollars & Pounds & Dollars & Pounds & Dollars & Pounds & Dollars & \\
\hline Buffalo.. & 7.700 & 840 & 500 & 60 & & . & 8,200 & 900 & 13.6 \\
\hline Carp.... & 7,900 & 865 & 700 & 70 & & . & 8,600 & 935 & 14.2 \\
\hline Catfish and & & & & & & & & & \\
\hline bullheads. & 6,800 & 1,120 & 500 & 125 & & & 7,300 & 1,245 & 18.9 \\
\hline Drum . & 5,100 & 620 & 100 & 20 & & 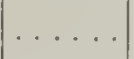 & 5,200 & 640 & 9.7 \\
\hline Mussel shells. & & $\ldots$ & . & & 104,000 & 1,560 & & & \\
\hline Pearls... & & & & & & 1,285 & 104,000 & 2,880 & 43.6 \\
\hline Slugs. . & & & & & & 35 & & & \\
\hline Total. & . & 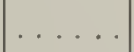 & & & & & 133,300 & $\$ 6,600$ & 100.0 \\
\hline
\end{tabular}

*Data from Sette (1925).

have a number of indices that reflect the relative importance of the two rivers from the point of view of fish production. These indices, showing that generally the Sangamon River is a somewhat more productive stream, are as follows.

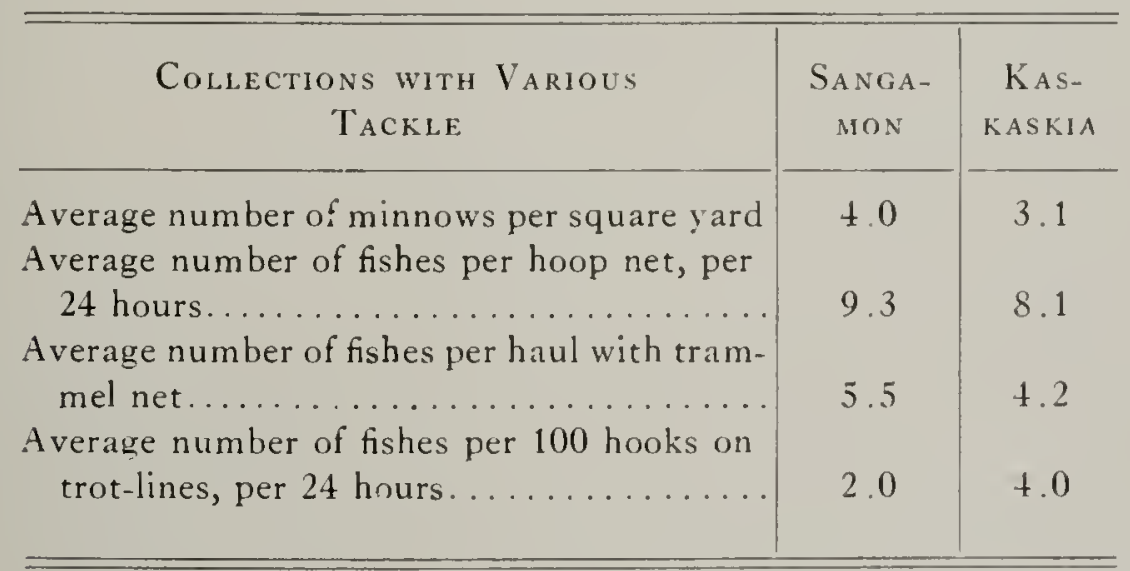




\section{KINDS AND NUMBERS OF MUSSELS}

FIVE general collections of mussels were made by hand at well distributed points on the Kaskaskia, with the various kinds appearing in the numbers shown in Table IV.

Table IV.-Kinds and Numbers of Mussels Taken in the Kaskaskia River from July 30 to September 1, 1929.

\begin{tabular}{|c|c|c|c|c|c|c|}
\hline \\
\hline \multicolumn{7}{|l|}{$\begin{array}{l}\text { UNIONINAE } \\
\text { Quadrula lachryn }\end{array}$} \\
\hline Quadrula pustulosa (Lea)....... & 3 & 8 & 3 & 11 & & 25 \\
\hline Tritogonia tuberculata (Barnes)... & 6 & 1 & 3 & 12 & & 22 \\
\hline Megalonais gigantea (Barnes)...... & & & & 11 & & 11 \\
\hline Amblema rariplicata (Lamarck)....... Three Ridge. & & & 3 & 10 & & 13 \\
\hline Amblema costata (Rafinesque)........ Three Ridge. & $\varepsilon$ & 8 & 1 & & & 17 \\
\hline Fusconaia flava (Rafinesque). & & 15 & 1 & 2 & & 18 \\
\hline Pleurobema catillus (Conrad)................. & $\varepsilon$ & 8 & 1 & & & 17 \\
\hline Elliptio dilatatus (Rafinesque)........ Ladyfinger.... & 6 & & & 1. & & 7 \\
\hline \multicolumn{7}{|l|}{ ANODONTINAE } \\
\hline Strophitus rugosus (Swainson)........ Squawfoot & 2 & 1 & 3 & 1 & & \\
\hline Anodonta grandis near var. plana (Lea).Papershell. & & & 1 & & & 1 \\
\hline Arcidens confragosus (Say)........... Rockshell. . & & & & 2 & & 2 \\
\hline Alasmidonta marginata (Say)... & 1 & & & & & 1 \\
\hline Lasmigona costata (Rafinesque). . & 3 & & & & & 3 \\
\hline Lasmigona complanata (Barnes)....... Heelsplitter. & 2 & 3 & 1 & 4 & & 10 \\
\hline \multicolumn{7}{|l|}{$L A M P S I L I N A E$} \\
\hline Obliquaria reflexa Rafinesque. & & & 1 & & & 1 \\
\hline Truncilla truncata Rafinesque..... & & & 1 & & & 1 \\
\hline Proptera alata (Say)............ & 2 & 5 & 1 & 4 & & 12 \\
\hline Leptodea fragilis (Rafinesque). & 2 & 1 & 19 & 3 & 29 & 54 \\
\hline Actinonais carinata (Barnes). & 26 & 16 & & 1 & & 43 \\
\hline Ligumia recta var. latissima (Rafinesque) Butterfly... & & & & 1 & & 1 \\
\hline Lampsilis ventricosa (Barnes)... & 3 & 11 & 17 & & 1 & 32 \\
\hline Lampsilis siliquoidea (Barnes).. & 4 & 12 & 7 & & & 23 \\
\hline Lampsilis anodontoides (Lea).... & & 1 & & & 3 & 4 \\
\hline Lampsilis fallacoisa (Smith).......... Slough Sandshell . & 2 & 5 & 10 & 6 & 3 & 26 \\
\hline & & & & & & 355 \\
\hline
\end{tabular}




\section{KINDS OF FISHES CAUGHT WITH VARIOUS TACKLE}

TABLE $V$ presents the hoop-net catches in the Kaskaskia River. The percentages in the last column of the table are summarized in Table VI and show that the hoop net catches consist predominantly of a few kinds of fishes. Thus the catfishes and bullheads make up 61 per cent of the entire catch, the sunfishes 28 per cent and all other kinds together the remaining 11 per cent. The high percentage of catfishes may be due to

Table V.-Fishes Taken by Hoop Nets, Kaskaskia River, 1929-1930.

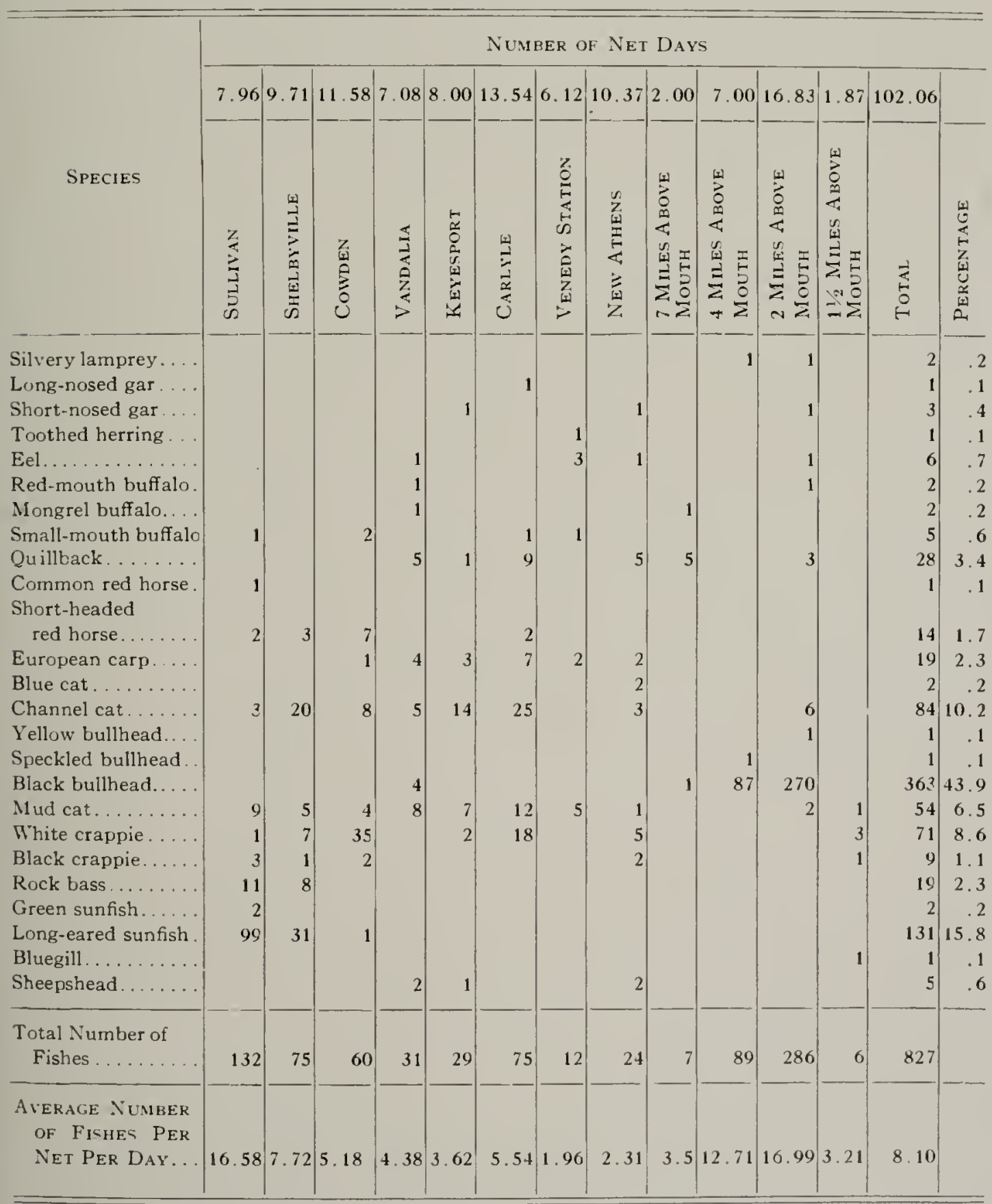


their seeking the hoop nets as places of concealment. Sunfish likewise seek concealment in brush and around stones and may also enter the hoop nets for the same reason. Suckers, carp and buffalo, being active and strong swimmers and seeking open waters as a rule, are rarely caught in smallmesh hoop nets. Table VI shows percentages of the different kinds of larger fishes caught by various kinds of tackle. The second column of this table shows the fishes caught by means of a trammel net. Though the total number caught by this method was very small, the proportion of the various kinds of fishes, even in such small numbers, indicates a marked contrast to the catch by hoop nets. More than half the trammel-net catch consists of suckers, carp and buffalo-the kinds that ordinarily avoid hoop nets. Sunfishes make up a much smaller percentage, and catfishes, which represented the largest percentage of the hoop-net catch, were not taken at all in the trammel net. Trot-line catches were so small as to lack significance except for the 13 carp, which were taken on soaked corn.

Table VI.-Comparison of Numbers and Kinds of Larger Fishes Taken with Different Kinds of Tackle.

\begin{tabular}{|c|c|c|c|}
\hline \multirow[b]{2}{*}{ KIND of Fish } & \multicolumn{3}{|c|}{ Number Taken } \\
\hline & $\begin{array}{c}\text { Hoop net, } \\
\text { 1-inch mesh, } \\
\text { with wings. } \\
102.1 \text { days }\end{array}$ & $\begin{array}{l}\text { Trammel net, } \\
1 \text {-inch mesh, } \\
6 \times 75 \text { feet. } \\
12 \text { hauls }\end{array}$ & $\begin{array}{l}\text { Trot-line- }-50 \\
\text { hooks baited } \\
\text { with soaked } \\
\text { corn, minnows } \\
\text { and fish. Set } \\
\text { for } 8.8 \text { days }\end{array}$ \\
\hline SUNFISHES & & & \\
\hline Rock bass. & 19 & & \\
\hline White crappie. & 71 & & \\
\hline Black crappie. & 9 & & \\
\hline Bluegill. & 1 & & \\
\hline Long-eared sunfish. . & 131 & 7 & \\
\hline Green sunfish...... & 2 & & \\
\hline Total.. & $233(28 \%)$ & $7(10 \%)$ & \\
\hline CATFISHES & & & \\
\hline Channel cat. . & & & 4 \\
\hline Blue cat......... & 2 & & \\
\hline Mud cat.......... & 54 & & \\
\hline Black bullhead. & 363 & & \\
\hline Speckled bullhead. & 1 & & \\
\hline Yellow bullhead... & 1 & & \\
\hline Total. . & $505(61 \%)$ & Continued & Next Page \\
\hline
\end{tabular}




\section{FACTORS AFFECTING THE ABUNDANCE OF FISHES IN THE KASKASKIA}

Since one of the aims of this reconnaissance of the Kaskaskia River was to obtain information on its fitness for the production of fishes, some general observations were made on the conditions in the stream as a basis for comparisons with other streams in Illinois.

Bottom.-The small bottom animals constitute the most important source of food fishes in this stream as well as in most of the other, larger Illinois streams. Rather extensive collections of bottom fauna are being worked over and a full account of their kinds and amounts will be included in a later report. Superficial inspection of the organisms found in the samples indicates that they occur in amounts common to Illinois streams of this size. The prevailing kind of bottom in the Kaskaskia is sand and

Table Vl.-Contd. Comparison of Numbers and Kinds of Larger Fishes Taken With Different Kinds of Tackle.

\begin{tabular}{|c|c|c|c|}
\hline \multicolumn{4}{|l|}{ 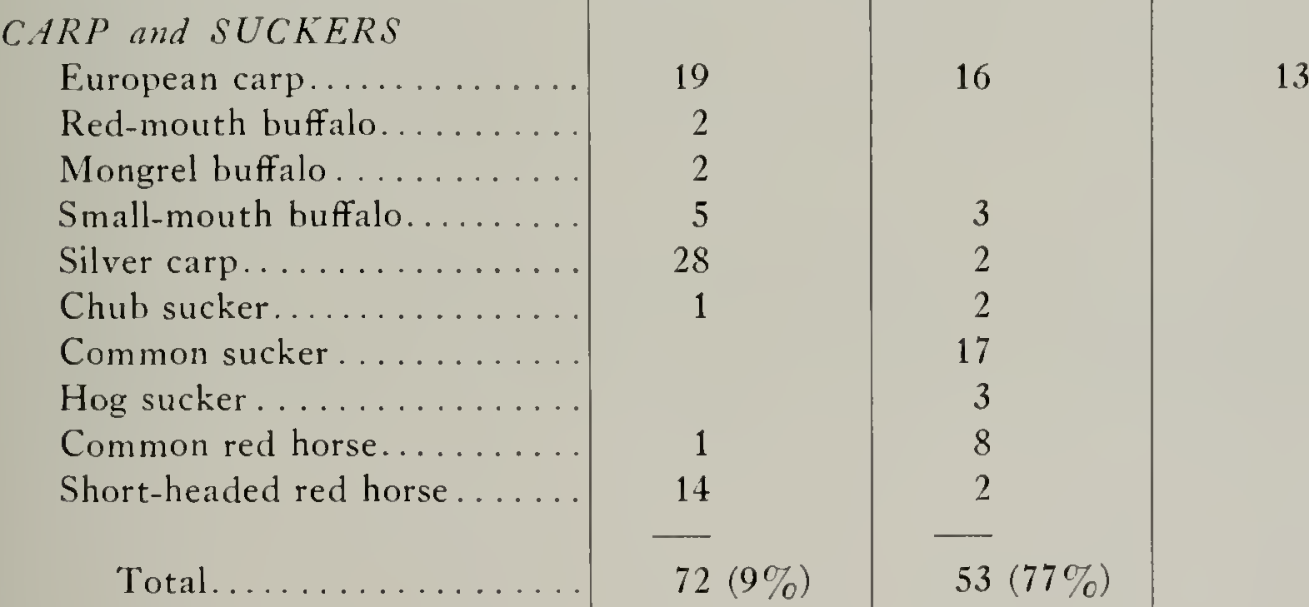 } \\
\hline 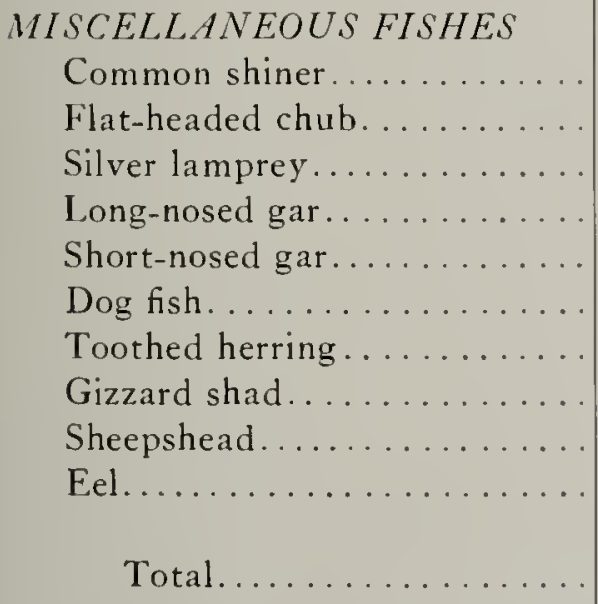 & $\begin{array}{c}1 \\
2 \\
1 \\
3 \\
1 \\
5 \\
6 \\
-19(2 \%)\end{array}$ & $\begin{array}{l}4 \\
2 \\
1 \\
2 \\
-9(13 \%)\end{array}$ & 1 \\
\hline Grand Total.......... & $829(100 \%)$ & $69(100 \%)$ & 18 \\
\hline
\end{tabular}


gravel. Exhaustive studies of the amounts of small bottom animals available as fish food on rock, gravel, sand, and mud bottoms have shown that sand is least productive, while gravel may be of intermediate or of superior productivity.

Plankton.-The few plankton collections taken in July and August, 1929 , seem to show that plankton is of very slight importance as a source of fish food in the main stream. Practically no plankton organisms were found in the collections except in the one taken just above the mouth

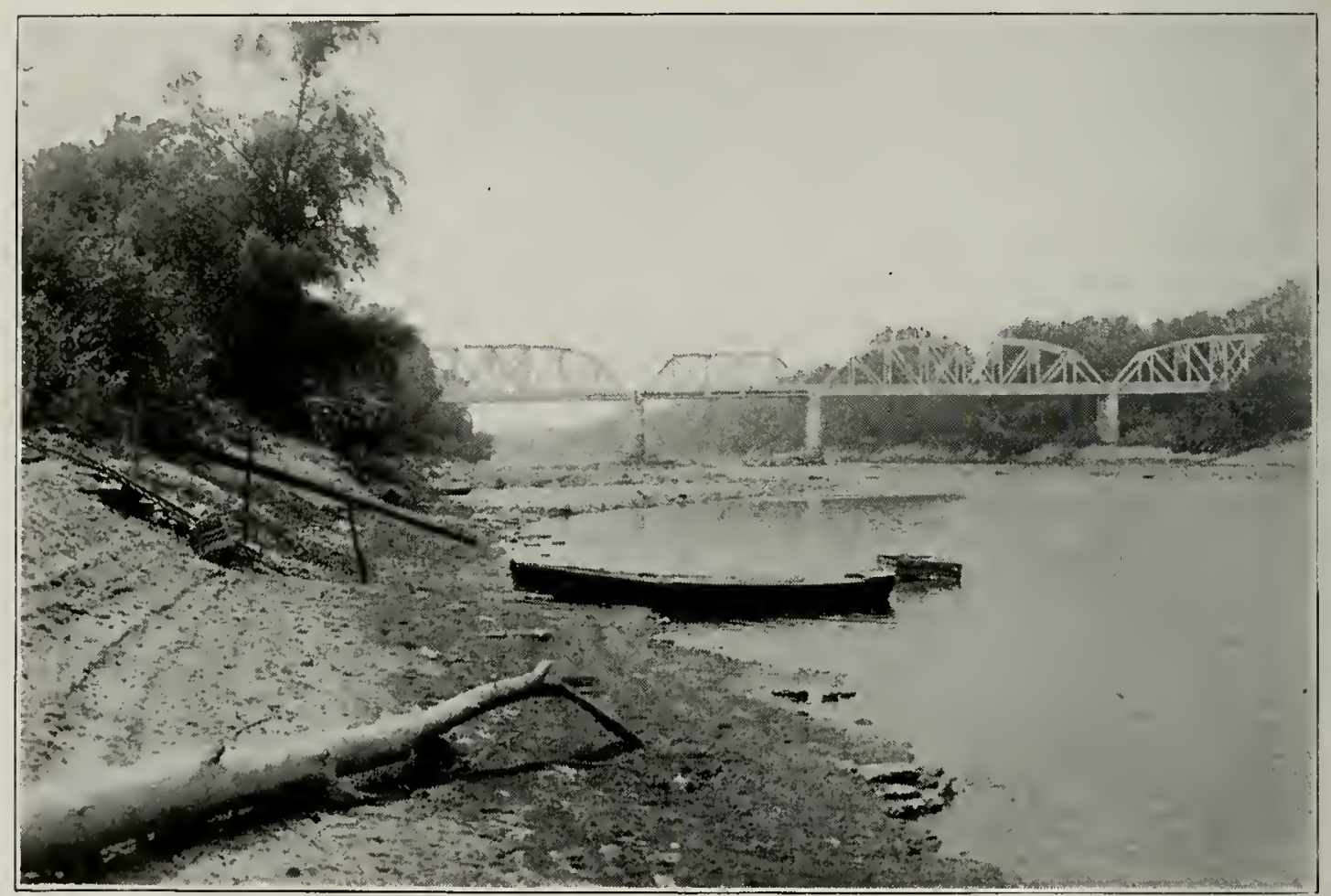

Fig. 8.-Kaskaskia River at Evansville, July, 1930.

of the river, and even this collection contained only 11 species, none of which was very abundant.

Vegetation.--Streams which have considerable amounts of submerged aquatic vegetation are quite commonly found to be our heaviest producers of fish. Such vegetation, besides serving directly as food for fish, provides favcrable situations for the production of large amounts of small animal life which serve as fish food. Such vegetation also provides cover and protection for many kinds of young fishes. Other studies of the ILliNoIS Natural History Survey have shown that the high fish productivity of the Illinois River is intimately associated with the wide areas of connecting bottomland lakes and sloughs. Along the course of the Kaskaskia through Bond, Clinton, Washington and St. Clair counties there are numerous floodplain lakes and sloughs, but the total area of these is so small that it is not likely that they materially affect the yield of fishes. The submerged 
aquatic vegetation of the Kaskaskia system is limited to the smaller headwater streams. The factors which seem to determine the presence or absence of submerged aquatic vegetation in Illinois streams are (1) turbidity, (2) nutritive substances brought in from the soils of the drainage basin and (3) constancy of flow. The turbidity of the Kaskaskia throughout most of its length is so great that light probably cannot penetrate the water sufficiently to allow the growth of submerged vegetation. Scarcity of nutritive substances for plants from the less fertile soils of the area covered by the Illinoisan glaciation may have something to do with the lack of vegetation. The water level in the Kaskaskia is subject to such variations that plants are either drowned or left stranded.

Enemies.-All game fishes feed for the most part upon minnows and other small fishes. Our minnow-seine collections show that there is a plentiful supply of this kind of food throughout the Kaskaskia River and that in number of minnows per square yard of water it compares favorably with other rivers of the state.

Natural enemies of fishes in the Kaskaskia appear to be of the same kinds and numbers as in other streams of the state, except for sporadic depredations of the lamprey, which will be described later. Thirty-two turtles were taken in the hoop nets during this survey, a number of which were large snapping turtles which commonly devour several fishes each day. Herons, kingfishers and other water birds which feed almost exclusively on fishes were noticed at many places. Minks, otters, muskrats and raccoons also take their toll of fish life.

Fishing.-From 1916 to 1930 commercial fishing was permitted in the lower reaches of the Kaskaskia. As shown by the reports of the United States Bureau of Fisheries (Sette, 1925), the important commercial kinds taken were carp, buffalo, catfish and sheepshead. Since buffalo and certain other suckers are rarely caught with hook and line their removal with nets and seines does not materially affect hook and line fishing. Commercial fishing may, however, reduce the numbers of carp, catfish and sheepshead available to hook and line fishermen. While bass, crappie and sunfish are supposed to be returned to the water when taken with commercial tackle. the temptation to keep these game fishes is very often too great. Continued operation of trot-lines may have some effect in lowering the numbers of certain kinds of fishes in the stream. During our survey we encountered several men who were making their living by catching sheepshead and catfish with trot-lines. One of these fishermen reported catches of 120 channel cat in a single night as not uncommon with the amount of tackle that he alone used.

Disease.-Practically all of the fishes taken in the course of this study appeared to be clean and healthy. This does not indicate, however, that 
disease is not an important factor affecting the abundance of fishes in the Kaskaskia, just as in other streams, since there is a wide variety of diseases which probably take a small but steady toll of fishes, with only an occasional outbreak which may kill off large enough numbers to be noticed. Dead fishes are quickly devoured by scavengers both in water and on land, and diseased or injured fishes with slow or erratic movements are easily caught by predators.

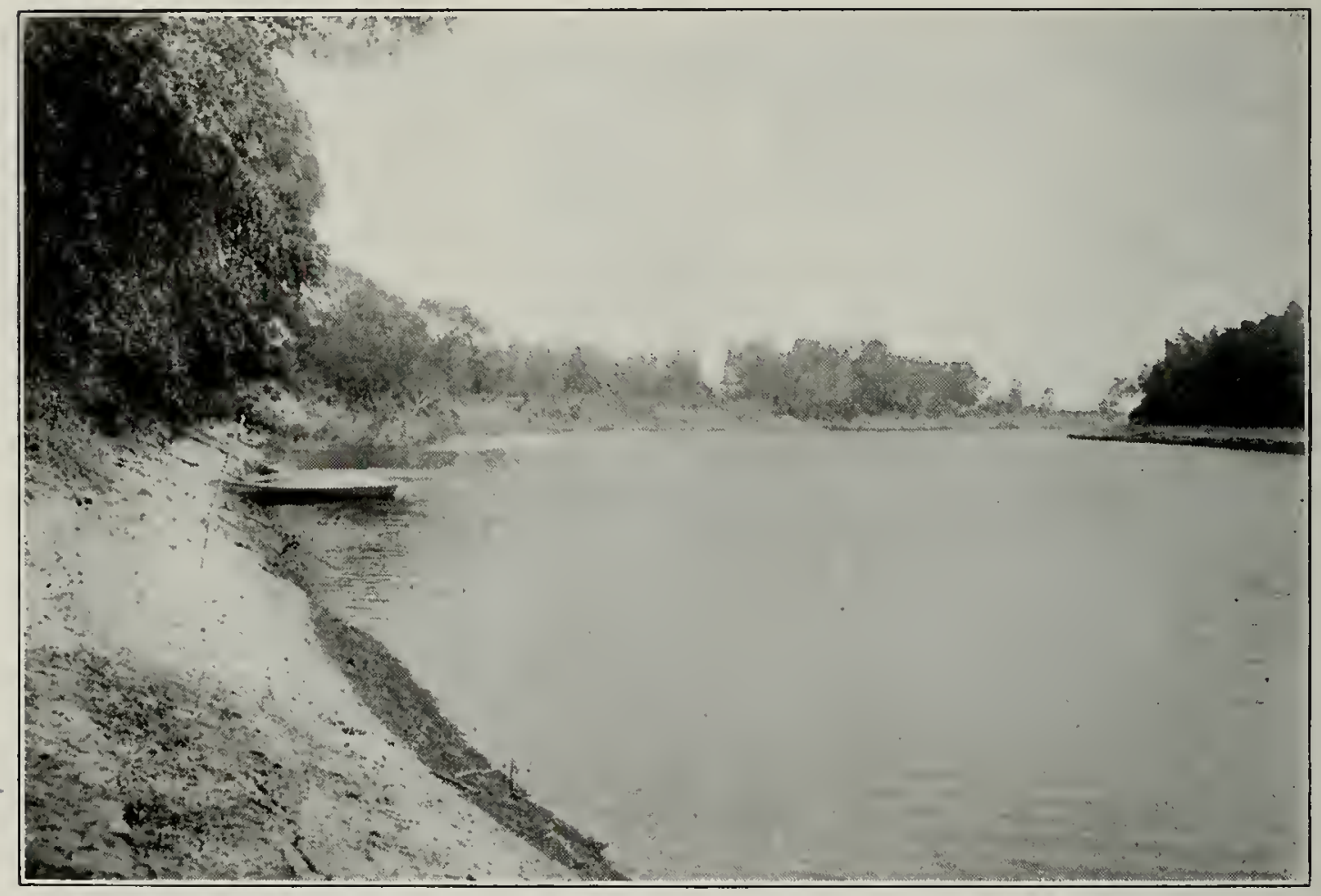

Fig. 9.-Kaskaskia River 2 miles above the mouth, July, 1930.

Pollution.-Finally, abundance of fishes is influenced by the amount and kind of pollution which a stream has to bear. The sewage load of the Kaskaskia, or Okaw, is small and has little effect except during periods of low water, when some stretches, especially in summer, may become heavily polluted. For example, a septic condition existed below Carlyle in July and August of 1930. The untreated domestic sewage which goes into the river at Carlyle is augmented by wastes from a strawboard factory and a milk plant. As a result of this pollution, for a distance of at least 25 miles downstream there was no dissolved oxygen in the water. Thousands of fishes were killed, and all the bottom animals, such as mussels and snails, must have perished also. The water was black, a layer of black sludge several inches thick covered the bottom and a strongly putrescent odor was apparent, even at some distance from the stream. Normally this. section of the river is a very productive one $: 3 a t=n$

About 100,000 people live in the Kaskaskia basin in towns and cities 
of more than 500 population. The river receives untreated sewage from about 17,000 of these people and effluent from treatment plants in cities representing a population of 65,000 . A remainder of some 20,000 persons resides in cities and towns with no sewer systems (Buswell, 1927).

Since the Kaskaskia basin consists predominantly of agricultural lands, without large industrial centers, the chief industrial wastes received by the river are such as result from treatment of agricultural products, particularly wastes from milk products plants and strawboard factories. In the southern part of the river basin there is considerable coal mining and a few limited areas which produce oil, but pumpage from these mines and wells is believed to have negligible effect on the river.

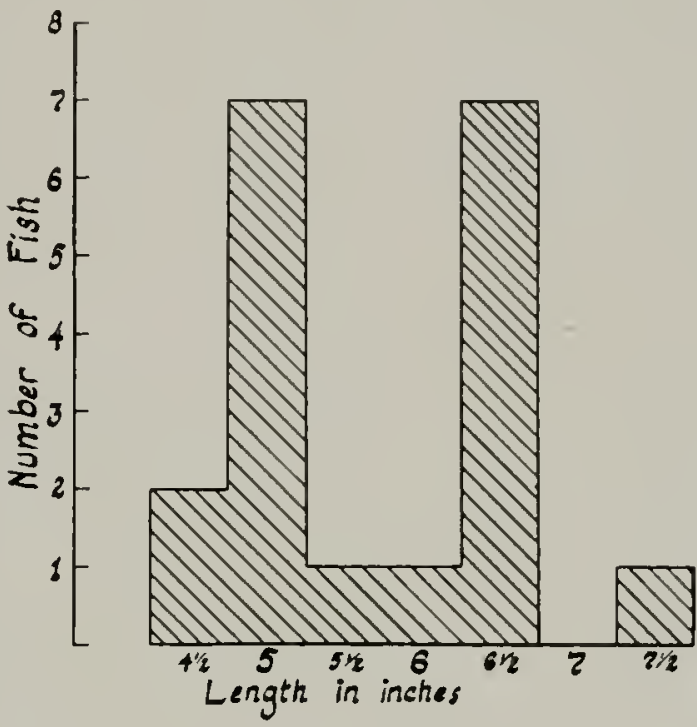

Fig. 10.-Age groups of rock bass.

\section{THE RATE OF GROWTH IN FISHES}

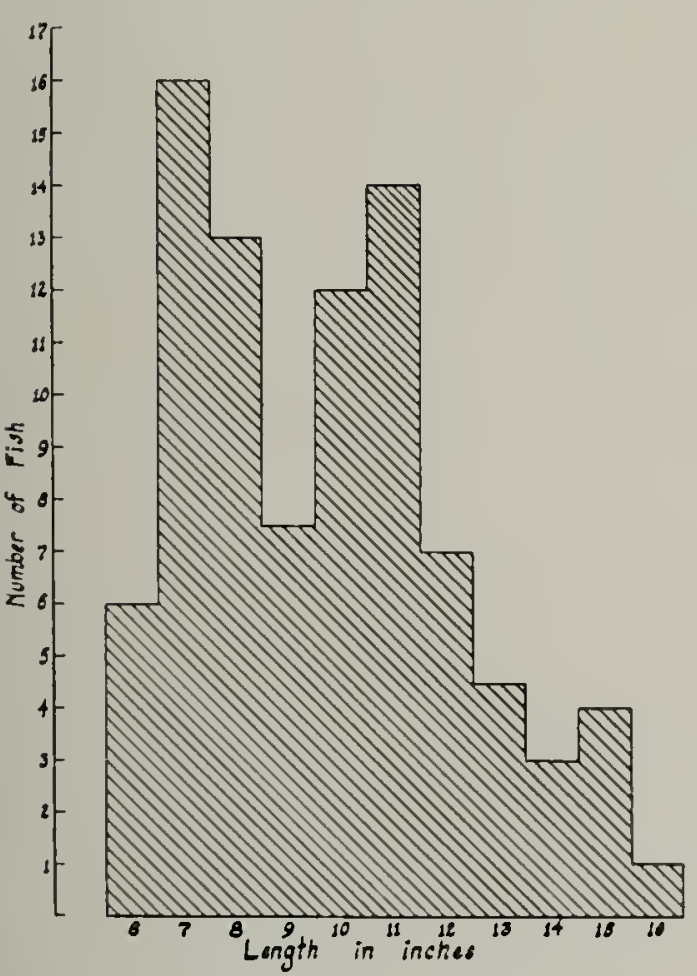

Fig. 11.-Age groups of channel cat.

Since most fishes spawn in a certain restricted season of the year and since the young grow at approximately the same rate, the different age groups can often be recognized. If the lengths of a considerable number of individuals of the same species taken from one area in a short period of time are plotted in the form of a frequency curve, these groups appear as humps in the curve. During the course of our study, data on the lengths of several species of fishes were obtained. These measurements were made from the tip of the snout to the base of the caudal fin. The data for rock bass, channel cat and mud cat show these age groups most distinctly and are presented in Figs. 10, 11 and 12. 
Figure 10 presents graphically the lengths of 19 rock bass. These measurements fall into two well separated groups, each representing a year class. One group, probably two years old, varies from $41 / 2$ to $51 / 2$ inches with a mode at 5 inches, while the other group varies from 6 to $71 / 2$ inches with a mode at $61 / 2$ inches and is made up presumably of three-year old fish.

In Fig. 11, which summarizes the data for 88 channel cat, three fairly well defined groups appear, presumably representing fishes two, three and

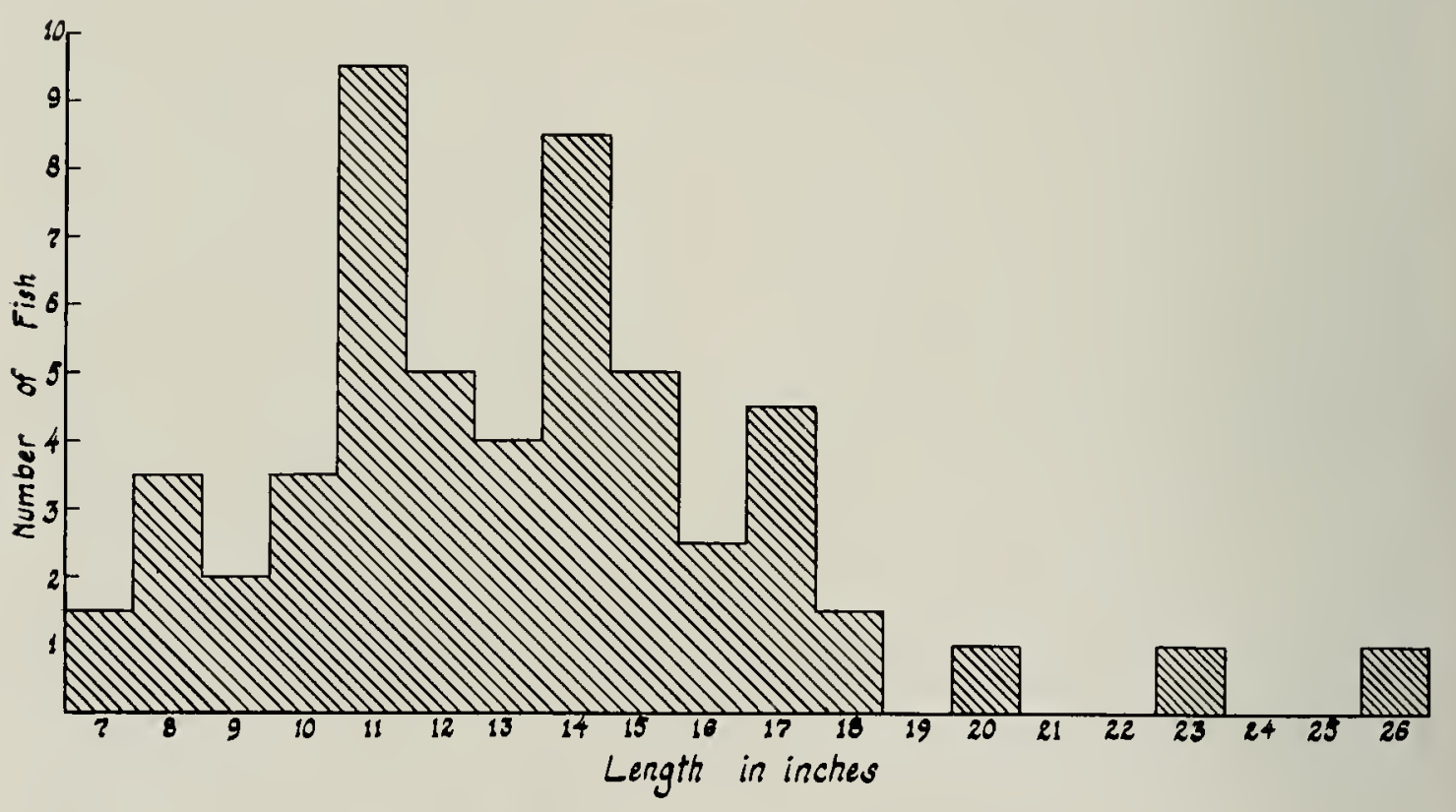

Fig. 12.-Age groups of mud cat.

four years old. Fishes of the first group vary from 6 to 9 inches with a mode at 7 inches; the second group, from 9 to 13 inches with a mode at 11 inches. Those of the third group appear to vary around 15 inches as a mode.

The data for mud cat are arranged graphically in Fig. 12, which shows modes at 8,11, 14 and 17 inches. The three individuals 20,23 and 26 inches in length may represent three additional year groups.

A better method of age determination is by examination of scales, spines and bones, which show annulations indicating the age and past history of individuals in much the same way as do the annual rings in the trunk of a tree. During the course of this study spines or scales were. taken from most of the fishes caught, and an analysis of these data will form the subject matter of later reports.

\section{THE FISHES OF THE KASKASKIA}

IN this section are presented some of the more obvious distinguishing characteristics of each of the larger fishes, a summary of known informa- 
tion concerning the life history of the more important ones, their food, their inter relation with other fishes, their usefulness, sizes, weights, distribution, etc. Those fishes which are rare or are so small as to be insignificant in the fishery have been treated very briefly, while the more important hook and line and commercial fishes have been treated more fully.

\section{LARGE FISHES}

\section{Silvery Lamprey}

\section{Ichthyomyzon concolor (Kirtland)}

The lamper eel is an elongate scaleless fish-like animal without paired fins, which reaches a length of 16 inches. It is also called lamper, river lamprey or silvery lamprey. By means of its mouth, which is expanded into a round sucking disc furnished with teeth for rasping, it attaches itself to larger fishes and rasps through the scales and into the flesh to feed on the blood.

Our records indicate that lampreys have their most serious effect during winter. In the study made on the lower Kaskaskia in the late summer of 1929 no lampreys were taken, and none of the large fishes upon which they commonly prey showed lamprey marks. In the field work on the lower Kaskaskia and in the Mississippi River near the mouth of the Kaskaskia in the late winter and early spring of 1930, numbers of lampreys were taken attached to carp, buffalo, spoonbill, catfishes and suckers. Mr. Barber, a commercial fisherman of Chester, said that in some winters the lampreys have destroyed nearly all of the carp in the lower Kaskaskia. Such an outbreak occurred during the winter of 1927-1928, and many tons of carp were destroyed and washed up dead along the banks. Less serious depredations occur nearly every winter. It is supposed that carp, being more sluggish than other fish in winter, fall an easy prey to lampreys.

While the important facts of the life history of the lake lamprey, Petromyzon marinus dorsatus Wilder, and of the brook lamprey, Lethenteron appendix (DeKay), have been well established, very little is known concerning the silvery lamprey. While our numbers and measurements of this lamprey were inadequate, members of the field party record the distinct impression of two or three size groups only in the lampreys caught, which would indicate that this species lives only a few years. The larger specimens appear to be especially voracious, and this increased consumption of food may be in preparation for sexual maturity and the production of eggs and milt. In all other lampreys, and probably in this one also, the production of the new generation causes such a drain upon the resources 
of the adults that they die soon afterward. We have noticed that the largest individuals are taken in late winter and spring and only medium sized ones in summer. This seems to indicate that the large adults die in spring.

\section{Spoonbill Cat; Paddlefish}

\section{Polyodon spathula (Walbaum)}

The spoonbill cat may be readily recognized by its large paddle-shaped snout. It is the most primitive of the bony fishes, and its nearest living relative is found in the large rivers of China. The paddle is considered to be a greatly enlarged sense organ, by means of which the fish detects the presence of those small organisms in the water which are its principal source of food. The paddle is waved back and forth as the fish swims along, with its mouth agape, straining the organisms from the water by means of its greatly elongated and numerous gill rakers. The spoonbill is usually held as an example of a fish that feeds exclusively upon plankton, but large numbers taken in the spring of 1930 in the Mississippi River at Chester contained nymphs of the mayfly, Hexagenia, and a few small fishes.

This is a highly prized market fish, selling (under the name of "boneless cat" or "spoonbill cat") when fresh at about the same price as channel cat or blue cat, and when smoked at about the same price as smoked sturgeon. Its roe is used for making caviar. Considerable numbers are regularly taken by commercial fishermen in the lower Kaskaskia and in the Mississippi near Chester.

Very little is known concerning the spawning habits and life history of this fish, in spite of the fact that many investigators have worked on the problem. Because of this we were especially interested to hear the fishermen report the presence of very small paddlefish in the Kaskaskia. Mr. H. C. Moore, a commercial fisherman of Chester, stated that he had seen spoonbill fry not more than 3 inches long in late summer in the lower reaches of the river. Both he and his partner were of the opinion that spoonbills spawn near the mouth of the Kaskaskia. Mr. Barber, another fisherman at Chester, said that he had seen young spoonbills about 4 inches long, also in late summer. The smallest specimen taken by us measured $71 / 2$ inches, including paddle and tail, and we have numerous specimens varying from this length to 12 inches over all, taken in the late winter and early spring of 1930. Since the spoonbills caught in the Kaskaskia rarely weigh more than 4 pounds and do not contain roe, it is difficult to see how any spawning occurs there unless the gravid adults visit the river only long enough, to spawn, departing before the seining season opens. 


\section{Gars}

\section{Lepisosteus osseus (Linnaeus)}

\section{Cylindrosteus platostomus (Rafinesque) \\ Lepisosteus platostomus Rafinesque ${ }^{3}$}

The gar-pikes may be recognized by their elongate cylindrical bodies, their beak-like jaws and the bony rhombic plates or scales that cover their bodies. In the long-nosed gar, Lepisosteus osseus, the beak is much longer and more slender than in the short-nosed gar, Cylindrosteus platostomus. Thus in the former the length of the beak is about 20 times the width near the tip, but in the latter only five or six times the width.

These alert and voracious fishes are very destructive, feeding on nearly all kinds of fishes, and competing with game fishes for food, so that they are capable of decreasing seriously the productiveness of streams where they are numerous. They are of no use whatever to man. For these reasons it is customary to destroy all gars caught. While common in the Kaskaskia, especially from Shelbyville to the mouth, they are not plentiful enough to have any very serious effect upon the fish life of the stream.

In the summer months, particularly in the more sluggish parts of the river, the gars may be seen "breaking" at the surface of the water, to renew the supply of air in their lung-like swim bladders-sticking out their beaks and opening and closing their jaws with a snapping sound. The swim bladder of these fishes is unique in that it is equipped with an abundance of small blood vessels and functions efficiently as a lung. Indeed, gars have been taken often in polluted waters with no dissolved oxygen, where they drown within a few minutes if held beneath the surface. The gills are small and seemingly inadequate, because the gars die sooner than other fishes if held in oxygen-deficient water.

\section{Alligator Gar \\ Atractosteus tristoechus (Schneider) \\ Lepisosteus tristoechus (Block \& Schneider)}

No specimen of the alligator gar was taken by us in the Kaskaskia, though fishermen state that this fish is common at certain times near the mouth of the river. It has a shorter beak than either of the aforementioned gars, and it grows to a much greater size, individuals measuring 10 feet in length and weighing 300 pounds having been seen in this vicinity. It also differs from the other gars in that the large teeth of its upper jaw are in two rows on each side instead of being in a single row.

${ }^{3}$ Nomenclature follows Jordan, "Manual of the Vertebrate Animals of the Northeastern United States." 1929, 13 th edition. Names in small type are those of Forbes and Richardson in "The Fisbes of Illinois," 1909. 
The following information regarding the alligator gar comes from Mr. Leslie Crow, of Chester, who fishes in the lower Kaskaskia.

A bout the first week in June, 1930, 75 to 100 gars entered an overflow pond on the river bottom about 2 miles above the mouth of the river. The pond was connected to the river by a cut in the bank, through which the fishes entered. The water was 2 to 4 feet deep in this pond, which consisted of a number of acres of wooded bottomland with considerable underbrush. May of these gars were judged to weigh 100 pounds, but a few of them were 10 feet long and may have weighed 300 pounds. The gars were spawning in this place, so that the shrubs, bushes, and other objects in the water were covered with eggs.

A special harpoon was made of a $3 / 8$-inch rake tooth. This was pointed and heavily barbed at one end. A loop in the middle of the shaft formed an attachment for a heavy line. The upper end was straight and blunt and fitted into a hole in the end of a long pole which served as a handle. When a hit was made, the pole was withdrawn, leaving the harpoon point. The line attached to the harpoon was 30 to 40 feet long and at its other end was attached a 10 -gallon can that was tightly sealed. Carrying this buoy and line, the fish finally exhausted itself and was taken.

Another method of catching alligator gar in this part of the river is by means of a large hook and a long line of quarter-inch rope. A special hook is made of quarter-inch spring steel and is baited with fish heads and the like. When a fish is hooked it is played from the bank until it is worn out, and then killed.

A number of people have stated that the eggs of these gars are poisonous. One man reported that roe from one alligator gar killed 90 chickens.

During the first week in August, 1930, several of these gars were seen about the piling at the mouth of the Kaskaskia. Another one was seen "rolling" on the surface of the water near Chester.

Such huge and voracious animals must levy a heavy tax upon the fish life of an area, and the number of fish destroyed by a single alligator gar during its lifetime must be very large.

\section{Dogfish; Bowfin}

\section{Amia calva Linnaeus}

This fish is known by many names, the more common of which are dogfish, bowfin, grindle and grinnel, the last being the name conmonly used by fishermen of the Kaskaskia. It is of little importance in this river, for it is comparatively rare and is not used to any extent as food. In our survey only one specimen ivas seen, and that was taken at Vandalia. Fishermen, however, vouched for the occurrence of the dogfish in other 
parts of the stream. It preys upon other fishes, crustaceans and mollusks.

\section{Toothed Herring; Moon Eye}

\section{Hiodon tergisus Le Sueur}

The toothed herring or moon eye was taken by us at three places, one specimen 2 miles south of Parkville near the headwaters of the Kaskaskia, one at Venedy Station about 50 miles from the mouth of the stream, and six young individuals 3 inches long about $11 / 2$ miles above the mouth. Though widely distributed in the stream, it is nowhere abundant and is of little importance to the fishery.

\section{Gizzard Shad}

\section{Dorosoma cepedianum (Le Sueur)}

The gizzard shad is abundant in the lower course of the Kaskaskia at certain seasons but is comparatively rare in the upper reaches. Two adults and eight fingerlings were taken in minnow-seine collections between Shelbyville and Venedy Station. This fish feeds on organic detritus on the bottom and on minute plant and animal life suspended in the water. Its preference for muddy bottom probably explains its rarity except near the mouth. Though not used by man for food, the gizzard shad in many streams and lakes of Illinois serves as the most important supply of animal food for game fishes. Gizzard shad fingerlings are often taken in quantities in the lower Kaskaskia and salted down for trot-line bait.

This species may be separated from the moon eye, which it superficially resembles, by the comparatively greater depth of the body, the great extension of the last rays of the dorsal fin and absence of a lateral line and of teeth.

\section{Eel}

\section{Anguilla bostoniensis Le Sueur Anguilla chrysypa Rafinesque}

'The eel is represented in our survey of the Kaskaskia by five specimens, four of which were tagged and released. One of these was recaptured a few hours later in a net about 50 yards upstream. One of the specimens taken at New Athens was 36 inches long and weighed 4 pounds. Reports from fishermen along the river indicate that eels are not uncommon from Shelbyville on down, although they are nowhere plentiful.

The eel feeds almost exclusively on fishes and is very voracious. The flesh contains somewhat more fat than most of our native fishes and is regarded as a delicacy by many people. On the market it brings about the 
same price as catfish. Considerable interest in its life history has been aroused in recent years following the discovery of its spawning grounds in the Sargasso Sea.

\section{Buffalo}

Megastomatobus cyprinella (Cuvier \& Valenciennes)

Ictiobus cyprinella (Cuvier \& Valenciennes)

Ictiobus urus (Agassiz)

\section{Ictiobus bubalus (Rafinesque)}

There are three species of buffalo fish, all of which are found in the Kaskaskia. Twelve specimens were collected from nine localities between Sullivan and the mouth of the river. Since eight of the 12 were the smallmouth, Ictiobus bubalus, this species seems to be more common than the other two in the Kaskaskia and to extend farther upstream. The commercial catch of buffalo in 1922 was 8,200 pounds valued at $\$ 900$ (Table III). Thus buffalo holds second place in weight and third place in value in the fishery of the Kaskaskia, being exceeded slightly in weight by carp and in value by catfish and carp. Mr. Hanke, manager of the fish hatchery at Carlyle, said that fishermen were catching buffalo in considerable numbers near Carlyle in August, 1930. The greater part of the catch was made with fyke nets and the rest with seines and set-lines.

The buffalo commonly attains a length of 3 feet and a weight of 50 pounds (Forbes and Richardson, 1909). The flesh is readily marketable at a price somewhat higher than that for carp. In Illinois it is usually preferred to carp in flavor and texture. Spawning occurs early in the spring, usually in April, and enormous numbers of eggs are shed around the margins of backwaters and sloughs. About a third of the food consists of vegetable material, and the rest is made up mainly of insects, entomostracans and mollusks.

According to Sette (1925), the buffalo is one of the few fishes that

\begin{tabular}{|c|c|}
\hline YEAR & Pounds \\
\hline 1894. & $.15,924,810$ \\
\hline 1899 . & $.14,215,975$ \\
\hline 1903. & $.11,491,663$ \\
\hline 1908. & $.15,040,000$ \\
\hline 1922. & $15,488,76$ \\
\hline
\end{tabular}


has maintained itself in undiminished numbers in the Mississippi River and its tributaries. The foregoing table shows the annual yield of buffalo fish in the Mississippi system for selected years from $189+$ to 1922.

\title{
Carp Suckers
}

\author{
Carpiodes carpio (Rafinesque) \\ Carpiodes difformis Cope \\ Carpiodes cyprinus (Le Sueur) \\ Carpiodes velifer (Rafinesque)
}

Three species of carp suckers were found in the Kaskaskia. They are also called native carp, river carp, silver carp, silvereens, quillback and spearback. Twenty-one specimens of Carpiodes carpio were taken and ten of these were tagged and released. Seven specimens of $C$. difformis were taken and two of them were tagged and released. Seven specimens of C. cyprinus were taken and three of them tagged and released.

The carp suckers are bottom feeders and are of little importance to the life of the stream. They form a small part of the commercial catch near the mouth of the river, but on account of their poor quality they are much the least profitable part of the catch, although they conpare favorably with other fishes when smoked.

\section{Common Sucker; Black Sucker}

\section{Catostomus commersonii (Lacépède)}

The common sucker, which is also called the fine-scaled or black sucker, may be distinguished from the other suckers by the large number and small size of the scales on the front half of its body. This sucker is found in tributaries and headwaters of the Kaskaskia but rarely in the main stream. Thus all but one of our 29 specimens were taken in the headwaters of the Kaskaskia in Champaign county.

The black sucker can be taken on worms in spring and makes up a large part of the catch by small boys. It ascends creeks and spawns on riffles in March and April. When caught in cold water, the flesh of this fish is white and firm and of good flavor. It is quite bony, however, and when taken from warm water the flesh is soft and unpalatable.

\section{Hog Sucker}

\section{Hypentelium nigricans (Le Sueur)}

\section{Catostomus nigricans Le Sueur}

The hog sucker may be recognized by its peculiar protusile sucking 
mouth and by its large broad square head. In the Kaskaskia it is confined to the upper third of the basin, which is the clearer and swifter part of the stream, where seven specimens were taken. This fish lives in the swifter parts of creeks, where it feeds from the bottom by rolling over stones and sucking up the material thus exposed. It maintains its position in swift water by resting upon its fins, but when alarmed it darts away in a zigzag course. In consequence of its feeding habits and its choice of habitat, it has assumed those structural adaptations characteristic of the darter family. It is occasionally taken on the hook but is not valued as food and is not important.

\section{Chub Sucker}

\section{Erimyzon sucetta oblongus (Mitchill)}

The chub sucker or sweet sucker is representd in our minnow-seine collections in the Kaskaskia by 93 specimens, all taken at Shelbyville or above. Its preferred habitat is in small streams. Since it never becomes very large it is not important commercially, but it is often used as bait in lieu of large minnows.

\section{Spotted Sucker}

\section{Minytrema melanops Rafinesque}

One spotted sucker was taken near Parkville. Though now rare in the Kaskaskia it was abundant there when Forbes and Richardson made their collections for "The Fishes of Illinois."

\section{Common Red Horse}

\section{Moxostoma aureolum (Le Sueur) ${ }^{4}$}

The 28 specimens taken in the course of this work show that this red horse is a common fish in the Kaskaskia. Nine adults were taken in the upper reaches of the river at Parkville and Sullivan, and 19 young were taken between Shelbyville and Venedy Station. The red horse shows a strong preference for the smaller clear rivers with sandy or rocky bottom.

Among the suckers this is one of the best for food, and it reaches a weight of 5 or 6 pounds. It appears on the market under the name of white mullet. It feeds mostly upon mollusks and aquatic insects and is readily taken in spring on hooks baited with worms. Its breeding season is in May and June, the adults ascending the smaller streams and spawning on the riffles.

${ }^{4}$ 'This and the following species of red horse, common thronghout Illinois, do not approximate closely any of the descriptions listed in Jordan (1929). 


\section{Short-headed Red Horse}

\section{Maxostoma breviceps (Cope)}

The short-headed red horse is distinguished from the common red horse by its tail fin, which is blood red instead of yellowish or pale orange, and by its distinctly smaller head. Sixteen adults were taken from five localities in the upper and middle reaches of the river, and $1+$ of these were tagged and released, but we have had no returns up to the time of writing. Its habits and table qualities are similar to those of the common red horse.

\section{Carp}

\section{Cyprinus carpio Linnaeus}

The carp may be distinguished from all other Illinois fishes by the four harbels found about its mouth and by the teeth on the spines of its anal and dorsal fins. This species is a native of Asia and was introduced eight or ten centuries ago into Europe, where it has been extensively cultivated. Its first introduction into this country in sufficient numbers to become established was in 1877. The first imports were distributed by the United States Bureau of Fisheries to private individuals who reared them in ponds. The fishes escaping from these ponds into public waters increased rapidly in number and became widespread.

Today the carp is one of the most important species in the inland fisheries of the United States. It forms a larger part of the fish yield of the Kaskaskia than any other species. Sette (1925) gives the catch of carp in 1922 in the Kaskaskia as 8,600 pounds valued at $\$ 935$.

The mirror carp, which has a few greatly enlarged and irregularly' shaped scales as well as smaller scales around the bases of the fins, was formerly very common in Illinois waters. In our work on the Kaskaskia only one specimen of this variety was taken.

That the carp is common in the Kaskaskia from its mouth up as far as Sullivan is indicated by our collections and by information from fishermen. We took 49 specimens in all, $3+$ of which were tagged and released in an effort to gain more definite information about the growth and movements of these fishes. The average weight and length of our specimens was $21 / 2$ pounds and $151 / 2$ inches, respectively.

There are many moot questions concerning the food of the carp. Cole (1904) concluded that a large proportion of the material in the alimentary tract was of vegetable origin, and Tracy (1910) found the chief part of the diet of carp to be made up normally of vegetable matter. Pearse (1918) states that young carp feed at first on entomostracans and rotifers, and then 
chiefly on insect larvae, but that adult carp are omnivorous, with vegetation forming a large part of their food. Forbes and Richardson (1909) state that the adult carp are "omnivorous feeders, taking principally vegetable matter, but insect larvae, crustaceans and mollusks, and other small aquatic animals as well." Smallwood and Struthers (1927) state that their studies of the food of adult carp of Oneida Lake clearly indicate a preference for animal food. Struthers (1928) examined the digestive tract of 42 adult carp from the barge canal and the Oswego canal, and his results show that the food of these carp consisted of 31.4 per cent plant material and 68.6 per cent animal matter. Struthers admits that carp show a selective preference for certain plant food, such as corn and potoatoes, which are much used for bait.

Since the carp is admittedly an omnivorous feeder, it seems probable that its diet varies under different conditions. Where no water plants or other vegetable materials are present the carp feeds almost exclusively upon animal material; where much plant material and little animal material are present the carp feeds upon the former; and where both are present it eats both. It is certain that in the main stream of the Kaskaskia carp depend a'most wholly upon animal food, as there is very little vegetation available. It may be added that an examination of the stomach contents of more than 100 carp from Illinois waters has failed to show any fish eggs or fish of any kind.

Carp usually lay their eggs in May and June, and less frequently throughout the summer. These hatch in 4 to 12 days, depending primarily upon the temperature of the water. The young carp grow very rapidly, often reaching a length of 6 inches or more and the weight of $1 / 2$ pound during the first summer. In a slough at Vandalia on August 15, 1929, 16 young carp varying from 4.3 to 5.1 inches in length (measured from the end of the snout to the base of the caudal fin) and weighing 2 to 3 ounces were taken by seining. These undoubtedly were of that season's hatch and indicate something of the rapidity of growth of young carp. At the end of the first year carp usually weigh a pound and at the end of the second, 2 pounds.

In many places carp have been condemned because of the detrimental effect they have upon game fishes, such as bass and crappie. Carp have been accused of eating the spawn and young of more desirable fishes, but there seems to be very little evidence to support this accusation. Since it appears that carp feed to a considerable extent upon animal matter, they are competitors of game fishes for food. On the other hand young carp probably serve as an important item of food for the larger game fishes, particularly black bass and wall-eyed pike. There seems to be some evidence, in other 
streams at least, that increase in the number of carp is accompanied by an increase in the number of bass.

Another common objection to the carp is that, by their method of feeding on the bottom and tearing up vegetation, they keep the water so roiled that the sun is unable to penetrate the water and aquatic plants are unable to grow. However, in a stream like the Kaskaskia, which is always carrying a great amount of suspended matter, natural turbidity prevents plant growth and the work of carp has negligible effect upon clearness of the stream.

Though very little is known about the subject, carp are usually considered to be nomadic but not migratory fishes. They spend the colder months in the deeper pools and ordinarily do not feed from October to March. So far we have but two returns from the $3+$ tagged individuals released in the Kaskaskia. One of these had traveled upstream 1/2 mile when it was retaken 8 months and 22 days later, the other had traveled downstream 20 miles and was taken 10 months and 6 days after its release.

\section{Blue Cat}

\section{Ictalurus furcatus (Cuvier \& Valenciennes)}

The blue cat or Fulton cat is the largest of the native catfishes, for it may grow to exceed 150 pounds. It is the characteristic catfish of the Mississippi River, and fishermen report that it is common in the Kaskaskia as far upstream as Cowden, about 200 miles above the mouth. Our collections, however, include only two small specimens 8 inches long, both taken in unbaited hoop nets at New Athens.

At Chester on the Mississippi, blue cats are caught by seining, by set lines and by "blocking," which is a perfected form of "jugging." From 15 to 25 molasses pails, gallon jugs or wooden blocks are used ats Hoats and tied at intervals of about 10 feet along a stout line. To each of these floats is tied a snell about 6 feet in length, with an $8 / 0$ hook. The large fresh-water shrimp, Palaemon ohionis Smith, is the preferred bait, although gizzard shad and other small fishes are often used. One end of the cord carrying the floats is fastened to a boat, and the fisherman with an occasional pull on the oars guides the line of blocks as it floats downstream. With this type of apparatus many large blue cats and mud cats are caught, especially in the summer months.

Coker (1929), from observations by Stringham, reported that the blue catfish breeds near Keokuk, Iowa, in June. In February and March. 1930, large numbers of blue cats 1 to 3 inches in length were taken in and 
about the mouth of the Kaskaskia.

The blue cat is predominantly a fish-eating species, although the successful use of large fresh-water shrimp for bait indicates that this crustacean, which is present in the Mississippi in large numbers from spring until autumn, may form a considerable part of the blue cat's food.

The blue cat is prized very highly as a food fish. Most anglers place it slightly below the channel cat in flavor and firmness of flesh, but it brings an equally high price. It may be separated from the channel cat by its greater depth in the shoulder region, its light blue color instead of slate tinged with bronze, and by the absence of dark spots which are usually present in the channel cat.

\section{Channel Cat}

\section{Ictalurus punctatus (Rafinesque)}

The channel cat or fiddler is the most abundant and probably the most important catfish of the Kaskaskia. Our collections included 131 specimens, of which 43 were young fry from 1 to 3 inches long, taken with the minnow seine during August, 1929. That the fry were found from Shelbyville to the mouth of the river indicates that this entire stretch of stream may serve as a breeding ground. Coker (1929) reports observations which indicate that it spawns in June and July at Keokuk. Pond culture experiments at Fairport were successful in that some fry were produced, but the number of young was very small compared to the number of breeding adults. Of the 88 adults taken in our collections 81 were tagged and liberated, but we have not yet had any returns. These averaged 12 inches long and $1 / 2$ pound in weight.

In some parts of the stream the channel cat is especially plentiful, one fisherman near Shelbyville reporting catches up to 120 from set lines in one night. Since this fish is a lover of swift water, the fishermen set their lines preferably at the head of rapids. Crayfish, dead minnows, clam meats and cheese are the usual baits. Forbes and Richardson's data, based on examination of 43 specimens from the Illinois and Mississippi rivers, indicate that it is an omnivorous feeder, vegetable matter making up about one-fourth of its food, and insects, mollusks and small fishes comprising the remainder.

While it is reported to reach a weight of 25 pounds, the largest channel cat taken in our smaller rivers like the Kaskaskia do not exceed 5 pounds. The flesh is white and firm and has a delightful flavor. It is the most highly prized of the catfishes as food, and by many anglers it is given first place among all fresh-water fishes. 


\title{
Bullheads
}

\author{
Ameiurus natalis (Le Sueur) \\ Ameiurus nebuiosus (Le Sueur) \\ Ameiurus melas (Rafinesque)
}

The black bullhead, Ameiurus melas, is by far the most abundant of the bullheads occurring in the Kaskaskia basin. The yellow bullhead, $A$. natalis, and the speckled bullhead, $A$. nebulosus, occur rarely. Thus 366 specimens of $A$. melas were taken in our survey but only three specimens of $A$. natalis and one of $A$. nebulosus. None of the bullheads is abundant in the main stream during the summer months. Only four specimens were taken during our work in August from Sullivan to the mouth of the river, and these were taken at Vandalia just after a rise of several feet following a shower.

Bullheads prefer sluggish and quiet waters, and this probably accounts for their absence from the main stream of the river during the summer. At this season they are in pools of creeks and in the lakes and overflow ponds of the river bottom. A few overflow ponds were seined and in each we found bullheads, usually adults and young.

In contrast to their scarcity in summer, bullheads were the fishes taken most abundantly in hoop nets near the mouth of the Kaskaskia in the early spring of 1930. This indication of a migratory habit among them is borne out by our returns from bullheads that were tagged. We have ten returns from the 281 black bullheads tagged in the spring of 1930 , all of which were originally taken near the mouth of the river (mostly within 2 miles) and were evidently coming in from the Mississippi. Five were retaken 1 day later at the same place at which they had been tagged. One was retaken 2 miles upstream 2 days after it had been released. Three were taken by a hook and line fisherman in a floodplain lake about 15 miles upstream 18 days after they had been tagged. One was retaken by another hook and line fisherman 28 miles upstream 63 days after it had been tagged. While these returns are too meager to warrant generalizations they do indicate that at this season bullheads are on the move and that they may travel considerable distances.

Bullheads are very hardy and can live under conditions other fishes cannot endure. They are omnivorous feeders. About one-fourth of their food is vegetable matter and the remaining three-fourths is made up mostly of aquatic insects, mollusks, crustaceans and other fishes. They spawn in May, June and July. Upon hatching, the young gather in a school and are guarded by the male. 


\section{Mud Cat; Goujon \\ Opladelus olizaris (Rafinesque) \\ Leptops olivaris (Rafinesque)}

The mud cat or goujon is the second largest of our catfishes. Individuals weighing up to 60 pounds are reported by fishermen as not at all uncommon. This fish probably ranks next to the channel cat in the commercial catch of catfishes on this river. It is a good food fish, rated about the same as bullheads but not quite as high as channel cat or blue cat.

The mud cat seems to be present in considerable numbers from Sullivan to the mouth. All of our 55 specimens were taken in hoop nets except. a single specimen, 4.5 inches long, taken in the minnow seine at Keyesport. These averaged 15 inches long and 11/2 pounds in weight. If the numbers caught by our nets give a fair indication, mud cat is most abundant in the central portion of the stream, from Sullivan to Carlyle. Absence of young from the minnow-seine collections indicates that the mud cat does not breed extensively in this stream, unless it happens that the young are normally found in situations which we did not sample.

This fish feeds almost entirely upon other fishes. One weighing about a pound, taken in our hoop nets near Shelbyville, had in its mouth a long-eared sunfish about 4 inches long.

While not as characteristic of rapid water as the channel cat, it reaches its greatest abundance in the swifter Illinois streams. It moves along the edge of banks and eddies in the current rather than in midchannel. During periods of low water some of the mud cats crawl into hollow logs and holes in the bank, and fishermen often take them from these holes with their hands or by hooking them through the jaw with a short stout hook.

We tagged 37 of the mud cats which we caught in the Kaskaskia. These varied from 7 to 26 inches in length and from .2 to 11 pounds in weight. Up to the present we have no returns from these fishes, but returns from other streams show rather extensive migrations.

\section{Grass Pike.}

\section{Esox vermiculatus Le Sueur}

The grass pike or little pickerel is the only representative of the pike family found in the Kaskaskia. Sixteen specimens were taken in our minnow-seine collections near the headwaters of the river. We have no record of the presence of this fish below Champaign county, though it probably occurs in tributaries entering farther down. It seems to be entirely carnivorous, with fish forming the bulk of its diet. Since it is a 
rather small fish, seldom growing to a length of 12 inches, it is not of importance to the angler. It appears to be most abundant in quiet waters with plenty of regetation in which it can hide and from which it can make dashes for its prey.

\section{Wall-eyed Pike}

\section{Stizostedion zitreum (Mitchill)}

Forbes and Richardson (1909) report the presence of wall-eyed pike, or pike-perch, in the Kaskaskia about 1900, but none have been taken in more recent collections. Fishermen along the middle reaches of the river stated that it was rarely taken.

\section{Sauger}

Cynoperca canadensis (C. H. Smith)

Stizostedion canadense griseum (DeKay)

Forbes and Richardson (1909) report the sauger as occurring in the Kaskaskia in former years, but we failed to obtain it in our collections.

\section{Large-mouth Black Bass}

Huro salmoides (Lacépède)

Micropterus salmoides (Lacépède)

The large-mouth black bass was not found in the channel of the Kaskaskia. It shows a preference for lakes, bayous and quiet waters, and is common in the overflow ponds and floodplain lakes of the Kaskaskia valley, since many of the brood fish in the Carlyle hatchery were obtained there.

Its food consists mainly of fishes and crayfish, with a few mollusks and insects. According to Evermann and Clark (1920) it feeds to some extent all winter, being caught in considerable numbers through the ice on Lake Maxinkuckee. It is a sportsman's fish and its propagation in artificial ponds for liberation in public waters has reached a high degree of development. Its flesh does not compare favorably with the best, such as wall-ered pike, bluegill and channel cat, but it is a fair food fish and is highly esteemed by many. It reaches a maximum weight of 8 or 10 pounds in this latitude.

\section{Small-mouth Black Bass}

Micropterus dolomien Lacépède

The small-mouth black bass is represented in our study by 15 young 
specimens taken with the minnow seine in the vicinity of Shelbyville, Cowden and Vandalia. While we failed to obtain adult individuals, fishermen report that during periods of clear water small-mouth bass are caught in stretches of the river from Shelbyville to Sullivan and for some distances above and below these points. This species shows a preference for clear swift water, in contrast to the large-mouth bass which prefers quiet water. Its food consists for the most part of fish and crayfish, with a few insects and mollusks.

This is a good food fish, slightly better than the large-mouth bass but somewhat inferior to the best grades of fresh-water fishes. For gameness it has a reputation even better than that of the large-mouth bass, and for this reason it is a favorite of sportsmen. It reaches a length of 15 to 20 inches and a maximum weight of 6 pounds.

The small-mouth bass may be separated from the large-mouth by the inferior size of its mouth and by the greater number of its scales. The posterior end of the upper jaw usually does not extend beyond the posterior border of the eye, while in the large-mouth bass it extends beyond this point. The number of rows of scales on the cheek is about 17 , while in the large-mouth the number is only ten or 11 .

\section{Green Sunfish}

\section{Apomotis cyanellus (Rafinesque) \\ Lepomis cyanellus Rafinesque}

The green sunfish is quite widely distributed in the Kaskaskia but it is not very abundant in any one locality. Thus 33 specimens were taken from 11 localities between Giblin near the headwaters and Nine Mile Creek near the mouth of the river. This is an excellent pan fish when large enough. It feeds mainly on insects, crustaceans and fishes.

\section{Orange-spotted Sunfish}

\section{Allotis humilis (Girard)}

\section{Lepomis humilis (Girard)}

This beautiful little fish is represented in our collections by $48 i$ individuals, 464 of which came from one locality near Vandalia and the rest from three other places. Thus it is likely to appear abundantly in one situation and be entirely absent from the same sort of habitat a few miles away. Seldom more than $31 / 2$ inches long, it is too small to be valuable as a food fish, and it may be considered a "weed" since it consumes food that may be useful to larger fishes. 


\title{
Long-eared Sunfish
}

\author{
Xenotis megalotis (Rafinesque) \\ Lepomis megalotis (Rafinesque)
}

The long-eared sunfish occurs very abundantly in the clearer swifter parts of the Kaskaskia in Douglas, Coles, Moultrie and Shelby counties. We did not find it in the river below Shelbyville. Of the $16+$ specimens taken 137 were adults, 23 of the largest of which were tagged before being released. This species is especially abundant near Sullivan, where we took 33 in one night in a 30-inch hoop net.

This species is a good pan fish but it is usually too small to be of much use for food. Our largest individuals were slightly over 5 inches long and weighed between 2 and 3 ounces.

\section{Bluegill \\ Helioperca incisor (Cuvier \& Valenciennes) \\ Lepomis pallidus (Mitchill)}

The bluegill was taken by us in but two localities. Three young individuals were taken with the minnow seine at Sullivan and one adult with the hoop net near the mouth of the river. It is so rare in the Kaskaskia that it is of very little importance.

Of all the sunfishes the bluegill is the largest and best from a food standpoint. According to Forbes and Richardson (1909), it reaches a length of 12 inches and a weight of $11 / 2$ pounds. It has excellent table qualities and in recent years has become a favorite with large numbers of Aly fishermen.

It prefers pond and lake waters but is common also in the larger rivers. It is an omnivorous feeder, sometimes subsisting entirely on vegetation, sometimes on insects, mollusks and other available animal food. Evermann and Clark (1920) state that it does not feed on other fishes, but Forbes and Richardson (1909) found the body of one darter in the stomach of a bluegill.

\section{Warmouth Bass}

\section{Chaenobryttus gulosus (Cuvier \& Valenciennes)}

One specimen of the warmouth was taken while we were seining for bait in a floodplain slough 3 miles below Carlyle. This species is most at home in the turbid waters of muddy lakes and sloughs, in contrast to the rock bass which prefers swift clear streams. It grows to a length of 10 inches and is a fair angler's fish, but its flesh often has a muddy flavor. 


\section{Rock Bass}

\section{Ambloplites rupestris (Rafinesque)}

The rock bass is represented in our collections by 23 specimens taken from four localities, of which 19 were adults taken at Sullivan and Shelbyville. These adults averaged $71 / 4$ inches long and weighed.$t$ of a pound (Fig. 10). Two young were taken at Vandalia and two at Venedy Station. Seventeen adults were tagged and released.

This fish shows a preference for swifter parts of the stream where the water is clear. It also occurs in clear, moderately deep lakes but is not so abundant in shallow warm waters. Our data indicate that it is limited to a rather restricted part of the Kaskaskia basin in Coles. Moultrie and Shelby counties where the river is not yet large and where the current is somewhat swifter than in the lower reaches.

The rock bass feeds mainly on insects, crustaceans and fishes. It is a good pan fish and attains a length of 12 inches and a weight of $11 / 2$ pounds. though the average is about $1 / \underline{\underline{ }}$ pound. It usually spawns in May and June. It will bite on almost any kind of animal substance, perhaps the best baits being small minnows, white grubs, grasshoppers, hellgramites and earthworms.

\section{White Crappie}

\section{Pomoxis annularis Rafinesque}

The white crappie is probably the most abundant game fish of the Kaskaskia. We took 72 adults and 17 young from ten localities ranging from Sullivan to the mouth of the river. All were caught in the main channel. We found no young in the river above Vandalia. Forty of the adults were tagged and released but no returns from them have been received. The adults averaged $71 / 4$ inches in length and weighed from 2 to 10 ounces.

Age determinations made on 61 white crappies taken at various points on the Kaskaskia River and of sizes commonly taken on hook and line were distributed as follows: one individual was in its second summer of growth, 37 were in their third summer, 18 in their fourth summer and five in their fifth summer. The lengths of crappies of different ages in the Kaskaskia have been given in the Introduction to this report.

The white crappie, on account of its abundance and table qualities, is one of the most important of the sunfishes. It is successfully propagated in hatcheries and is one of the best of fishes for stocking artificial ponds, especially those which fluctuate in level and tend to be turbid. It has a wide range of adaptability and occurs most abundantly in larger streams 
and quiet waters such as lakes and ponds. Its food consists entirely of animal material and is mostly insects, crustaceans and small fishes. It takes the bait readily especially if small live minnows are used.

\section{Black Crappie}

\section{Pomoxis sparoides (Lacépède)}

The black crappie or calico bass is much less common in the Kaskaskia than is the white crappie. Only ten specimens from six localities were taken in our nets. These localities, however, were spread the length of the river, from Sullivan to the mouth. Nine of these fishes were tagged and released. Besides the difference in coloration this crappie may be separated from the white crappie by its comparatively greater depth of body and by the number of spines in its dorsal fin, which is usually seven or eight instead of six as in the white crappie.

The general range of the black crappie extends farther northward than that of the white crappie, but not as far south. In feeding habits it is much like the white crappie, and for this reason is caught by the same methods. Both white and black crappies usually spawn in May.

\section{Sheepshead; Drum}

\section{Aplodinotus grunniens (Rafinesque)}

The sheepshead, drum or white perch forms a considerable part of the commercial catch of the fishery of the Kaskaskia. In 1922, according to the United States Bureau of Fisheries (Sette, 1925), the catch of this species was 5,200 pounds and was valued at $\$ 640$. This was more than one-sixth of the total commercial catch in that year.

Our five specimens were taken at three localities-Vandalia, Carlyle and New Athens. Hook and line fishermen report that the sheepshead is common as far up the river as Shelbyville.

The sheepshead is notable for its powerful pharyngeal jaws and millstone-like teeth by means of which it is able to crush the shells of many fresh-water mollusks. Because of its food relation to the mussels it becomes heavily loaded with their glochidia, which, after a short period of parasitic existence, drop to the river bed and develop into adult mussels. Thus, in some measure, it pays for its food by nourishing the young of the mussels and at the same time carrying them over wide areas and finally dropping them where they may develop and in turn serve it as food.

This fish receives its common name, drum, from the peculiar drumming sound it makes. This sound is believed to result from the rapid contraction of two bands of muscles that set up vibrations in the wall of the air bladder, which thus acts as a resonator. 
There are differences of opinion as to the quality of the flesh of this fish for food. Large drums are said to be very inferior in quality, becoming stringy and unpalatable with age, but the small drums have a good flavor and a ready sale. The hook and line fishermen of the Kaskaskia consider the drum of that stream to be a fine pan fish. The flesh is somewhat more oily than that of other Illinois game fishes. According to Coker (1929), drums from the inland lakes of Minnesota and Wisconsin are very inferior in quality and are of no value as food, while those of Lake Keokuk, and Lake Pepin are usually considered good.

Little is definitely known concerning the breeding habits of this fish. Fry 3/4-inch to 2 inches long were taken in the Sangamon River, both above and below the Decatur dam, between July 18 and July 30 in 1929 . Fry $1 / 2$ to $1 \frac{1}{2}$ inches long were seen on sand bars of the Mississippi along the Chester water front August 1, 1930. The size of these fry would indicate that in this latitude the breeding season is in June, perhaps extending into July.

The drum grows to a large size, attaining a weight of 50 to 60 pounds. Such large individuals, however, are unusual and almost unknown now, and most of those caught in the Kaskaskia weighed from $1 / 2$ pound to 3 pounds, with only occasional individuals weighing 10 pounds or more.

lt will take a wide variety of animal baits and will bite on spinners and spoonhooks. It may be considered a game fish in the Kaskaskia.

\section{SMALL FISHES}

\section{The Minnows}

Native minnows of the Kaskaskia are small scaled fishes with a single dorsal fin. A few kinds may occasionally reach an extreme length of 8 or 10 inches, but we usually think of them as not exceeding a finger's length. They are a staple in the diet of our large carnivorous game fishes and are everywhere a favorite bait. Most kinds of minnows feed primarily on insects and small crustaceans, with a few others feeding on plant material, and still others feeding on organic detritus from the bottoms of our ponds and streams. Of the 8,540 fishes of all kinds taken by various inethods in the course of this survey, 6,276 were minnows.

In the following list of species the number of collections in which each kind occurred is given, as well as the total number of specimens of eacl kind. 
Notemigonus crysoleucas (Mitchill). [Abramis crysoleucas (Mitchill)].Golden shiner. 13 colls. 120 spms.

This excellent bait minnow reaches a length of 6 to 8 inches. Most of the specimens were taken in the headwaters of the Kaskaskia with snaller numbers in the lower reaches of the main channel. It is found most numerous where the water is quiet and about aquatic vegetation or other cover. It spawns from May until August. The golden shiner has come into prominence in recent years as a forage fish in the propagation of bass, crappies and bluegills in ponds.

Opsopoeodus emiliae Hay.-Snub-nosed minnow. 2 colls. 3 spms. Length, $2 \frac{1}{4}$ inches.

Semotilus atromaculatus (Mitchill).-Horned dace. 14 colls. 217 spms. Common in the Kaskaskia basin. Most abundant in the smaller tributaries. It grows to 6 or 8 inches in length and is a fine and hardy bait fish. Ripe females and males were found in May, 1930, and the eggs were readily stripped and fertilized by milt from the males.

Notropis atherinoides Rafinesque.-River shiner. 6 colls. 285 spms.

This long slender minnow is found most abundantly in larger rivers and lakes. In the Kaskaskia it occurs from Vandalia to the mouth. It reaches a length of $21 / 2$ to $4 \frac{1}{2}$ inches and is often used as bait.

Lythrurus umbratilis cyanocephalus (Copeland). [Notropis umbratilis atripes (Jordan)].-Blackfin minnow. 12 colls. 195 spms.

Common in the tributaries of the Kaskaskia and in the main channel as far downstream as Shelbyville. Length, 3 inches.

Luxilus cornutus (Mitchill). [Notropis cornutus (Mitchill)].-Common shiner. 17 colls. 516 spms.

Found in the creeks of the Kaskaskia basin, abundant in tributaries in Champaign county. Length, 5 to 8 inches. It is our most important bait fish since it can be transported easily and is active and lives well on the hook. It spawns in May and June, depositing its eggs in the nests of other nest-building fishes such as the Kentucky chub and the horned dace.

Luxilus cornutus (Mitchill) $\times$ Nocomis biguttatus (Kirtland).-Hybrid. 2 colls. 7 spms.

Identified by Dr. Carl L. Hubbs. Formerly designated as Notropis pilsbryi Fowler. 
Luxilus cornutus (Mitchill) $\times$ Hybognathus nuchalis Agassiz.-Hybrid. 1 coll. $1 \mathrm{spm}$.

Identified by Dr. Carl L. Hubbs.

Cyprinella whipplii (Girard). [Notropis whipplii (Girard)].-Silverfin. 19 colls. 1041 spms.

Very abundant in the Kaskaskia from Parkville to the mouth.

This is characteristically a swift-water minnow and makes excellent bait. Length, 3 to 4 inches. Spawns in summer, May to August.

Cyprinella lutrensis (Baird \& Girard). [Notropis lutrensis (Baird \& Girard)].-Redfin.

Reported by Forbes and Richardson (1909) from the Kaskaskia. Length, 2 to 3 inches.

Hybopsis hudsonius (De Witt Clinton). [Notropis hudsonius (De Witt Clinton)].--Spot-tailed minnow.

Reported by Hankinson (1913) from Crabapple Creek, in Coles county. Length, 4 to 6 inches.

Hybopsis deliciosus (Girard). [Notropis blennius (Girard)].-Strawcolored minnow. 16 colls. 248 spms.

Common throughout the Kaskaskia. Length, $2 \frac{1}{2}$ inches.

Hybopsis blennius (Girard). [Notropis jejunus (Forbes)]. 1 coll. 50 spms.

Length, 2 to $2 \frac{1}{2}$ inches.

Hybopsis boops Gilbert. [Notropis illecebrosus (Girard)].-Big-eyed minnow. 2 colls. 12 spms.

Taken near Sullivan. Length, 3 inches.

Platygobio gracilis (Richardson).-Flat-headed chub. 1 coll. 12 spms.

Found in lower reaches of the Kaskaskia. Length, 10 to 12 inches.

Nocomis biguttatus (Kirtland). [Hybopsis kentuckiensis (Rafinesque)].Hornyhead; Kentucky chub. 13 colls. 446 spms.

Abundant in headwaters of the Kaskaskia in Champaign county. Since the hornyhead grows to 8 or 10 inches in length fly fishermen sometimes find good sport whipping for it on riffles in clear creeks. Spawning begins in late May and early June, and extends into August.

Erinemus storerianus (Kirtland). [Hybopsis storerianus (Kirtland)].Storer's chub. 5 colls. 71 spms. 
One of the largest of our native minnows found in larger rivers and lakes. In the Kaskaskia it was found as far upstream as Cowden. It grows to a length of 10 inches and spawns in June and July.

Erinemus hyalinus Cope. [Hybopsis amblops (Rafinesque)].-Big-eyed chub. 6 colls. 45 spms.

Taken in the Kaskaskia at Sullivan and points further downstream.

Length, 2 to 3 inches.

Erimystax dissimilis (Kirtland). [Hybopsis dissimilis (Kirtland)].Spotted shiner.

Reported from the Kaskaskia by Forbes and Richardson (1909). Length, 3 inches.

Macrhybopsis gelidus (Girard). [Hybopsis gelidus (Girard)]. 1 coll. $1 \mathrm{spm}$.

Taken with beam trawl 2 miles above the mouth of the Kaskaskia. Length, 3 inches. Jordan (1929) states that it is a species of large river channels.

Extrarius hyostomus (Gilbert). [Hybopsis hyostomus (Gilbert)]. 1 colls. 39 spms.

All taken in a beam trawl at one locality $1 \frac{1}{2}$ miles above the mouth of the river. This species is very small, seldom reaching $13 / 4$ inches in length.

Ericymba buccata (Cope).--Silver-mouthed minnow. 18 colls. 526 spms.

Taken in small numbers in the headwaters of the Kaskaskia and in the lower reaches of the main channel usually over sand and gravel bottom. It spawns in April and May. Length, 3 to 4 inches.

Phenacobius mirabilis (Girard).-Sucker-mouthed minnow. 8 colls. 81 spms.

A minnow which prefers creeks and small rivers where it is found on the swiftest riffles. Length, $31 / 2$ inches. It spawns in late May and early June.

Hybognathus nuchalis Agassiz.-Silvery minnow. 22 colls. 785 spms. A large pale minnow common in the Kaskaskia basin. It is so soft and sensitive that it is unsuitable for bait.

Ceratichthys vigilax Baird \& Girard. [Cliola vigilax (Baird \& Girard)].Bullhead minnow. 13 colls. 428 spms.

Common in larger rivers, occurring between Sullivan and the mouth in the main channel of the Kaskaskia. Length, 2 to 3 inches. Breeding season in late May and early June. 
Hyborhynchus notatus (Rafinesque). [Pimephales notatus (Rafinesque)].

-Blunt-nosed minnow. 28 colls. 1069 spms.

The most widely distributed and abundant minnow of the Kaskaskia. Adults 2 to $3 \frac{1}{2}$ inches in length. A very common bait minnow. It begins spawning in late May and early June, the season extending into late summer.

Pimephales promelas Rafinesque.-Fathead minnow; black-head minnow. 4 colls. 11 spms.

Found occasionally in the channel of the Kaskaskia. Length, $21 / 2$ inches. Spawning season extends throughout the summer. This minnow is coming into use as a forage fish in the pond culture of game fishes. It is also well adapted for laboratory use since a few ripe eggs can be stripped from breeding females each day over long periods and fertilized by milt stripped from males.

Campostoma anamolum (Rafinesque).-Stoneroller; doughbelly. 2 colls. 24 spms.

An excellent bait minnow reaching a length of 6 inches. Breeds from March until May. Breeding males covered with tubercles. Common in creeks and small rivers with swift water and rocky or gravelly bottom. Scarce in the Kaskaskia basin.

\section{The Stonecats}

These little catfishes present the same general appearance as their larger relatives. They are unique, however, in that they are equipped with poison glands and can inflict extremely painful wounds with their spines.

Noturus flavus (Rafinesque).-Stonecat.

Reported from the Kaskaskia by Forbes and Richardson (1909).

Schilbeodes gyrinus (Mitchill).-Mad Tom; tadpole cat. 1 coll. 4 spms.

Taken at one locality near the mouth of the river. Forbes and Richardson's data show that it formerly was common in this river. Length, 3 to 5 inches.

Schilbeodes nocturnus (Jordan \& Gilbert).-Freckled stonecat. 3 colls. 10 spms.

From Vandalia, Keyesport and Venedy Station in the middle reaches of the river. Habitat characterized by very swift water with rocky or sandy bottom. Length, not over 3 inches. 
Rabida exilis (Nelson). [Schilbeodes exilis (Nelson)].-Slender stonecat. 1 coll. $1 \mathrm{spm}$.

Taken near Sullivan. Length, 3 to 4 inches.

Rabida miurus (Jordan). [Schilbeodes miumus (Jordan)].-Brindled stonecat.

Reported from the headwaters of the Kaskaskia by Forbes and

Richardson (1909). Length, 31/2 inches.

\section{The Darters}

The darters are small scaled fishes with two dorsal fins, and are usually strikingly marked with bars and blotches. Breeding males are very highly colored and exhibit brilliant greens, blues, reds and blacks. They habitually rest on the bottom and move by crawling with their fins, or by swift dashes. Most kinds are to be found hiding under and among rocks and other cover on the riffles of brooks and creeks.

While they eat insects and other animal food almost exclusively they are relatively insignificant in the economics of our waters, since they are very small both in size and numbers.

Percina caprodes (Rafinesque).-Log perch. 2 colls. 2 spms.

One taken near Bondville and another at Vandalia. Thirty or more years ago Forbes and Richardson found it common in the headwaters of the Kaskaskia. This is the largest of the darters, occasionally exceeding 6 inches in length.

Alvordius phoxocephalus (Nelson). [Hadropterus phoxocephalus (Nelson)].--Sharp-nosed darter. 5 colls. 73 spms.

Common in the middle reaches of the Kaskaskia from Sullivan to Carlyle. Length, 3 inches. Most numerous in swift waters of larger creeks and small rivers with a sandy or rocky bottom.

Alvordius maculatus Girard. [Hadropterus aspro (Cope \& Jordan)].Black-sided darter. 7 colls. 11 spms.

From seven localities between Ivesdale and Vandalia. Length, 3 to 4 inches.

Ericosma evides (Jordan \& Copeland). [Hadropterus evides (Jordan \& Copeland)]. 1 coll. $1 \mathrm{spm}$.

Collected near the mouth of the Kaskaskia. Length, 3 inches.

Imostoma shumardi (Girard). [Cottogaster shumardi (Girard)].

Reported by Forbes and Richardson (1909) from two localities on the Kaskaskia. 
Boleosoma nigrum (Rafinesque)-Johnny darter. 21 colls. 136 spms. Very widespread and abundant in the Kaskaskia basin, though not found in the main course of the river below Vandalia. It shows a preference for creeks and brooks. Length, $2 \frac{1}{2}$ inches. Breeding usually in May and June.

Vaillantia camura (Forbes). [Boleosoma camurum (Forbes)].-Snubnosed darter. 7 colls. 83 spms.

Common in the channel of the Kaskaskia below Cowden. Length, $13 / 4$ inches.

Vigil pellucidus (Baird). [Ammocrypta pellucida (Baird)].-Sand darter. 9 colls. 47 spms.

Common in the main course of the river from Shelbyville to Venedy Station. Has the habit of burying itself in sand with all but its head covered. Length, $21 / 4$ inches.

Oligocephalus coeruleus (Storer). [Etheostoma coeruleum Storer].Rainbow darter. 1 coll. 9 spms.

Taken only in Reilly Lake Creek which joins the Kaskaskia near its mouth. Length, $2 \frac{1}{2}$ inches. The male of this species is very brilliantly colored in reds and blues.

Oligocephalus jessiae (Jordan \& Brayton). [Etheostoma jessiae (Jordan \& Brayton)]. 2 colls. 2 spms.

One collected at Keyesport and another in Nine Mile Creek. Length, 2 inches.

Catonotus flabellaris (Rafinesque). [Etheostoma flabellare Rafinesque.]Fantail darter.

Reported by Forbes and Richardson (1909) from the Kaskaskia near Cowden. Length, $2 \frac{1}{2}$ inches.

Hololepis fusiformis (Girard). [Boleichthys fusiformis (Girard)]. 2 colls. 14 spms.

Taken at two localities near the mouth of the river. Forbes and

Richardson (1909) formerly reported it from several localities in the middle course of the Kaskaskia. Length, 2 to $2 \frac{1}{2}$ inches.

\section{Miscellaneous Small Fishes}

Zygonectes notatus (Rafinesque). [Fundulus notatus (Rafinesque)].Top minnow. 11 colls. 58 spms.

Common throughout all parts of the Kaskaskia. Length, 2 to 3 inches. Probably spawns in June. 
Gambusia patruelis (Baird \& Girard). [Gambusia affnis (Baird \& Girard)].-Viviparous top minnow. 5 colls. 60 spms.

Common in the Kaskaskia from Vandalia to Venedy Station. Length, $11 / 2$ to 2 inches. Males fewer than females. Fggs held within body of female until young are well developed. Several broods in a season.

Aphredoderus sayanus (Gilliams).--Pirate perch. 6 colls. 106 spms. Abundant in the headwaters of the Kaskaskia in Champaign county. Prefers streams with considerable aquatic"vegetation in which to hide. Length, 4 inches. Anus at throat. Its food is made up mainly of animal material, fishes forming a small proportion, with insects making up the bulk. The breeding season is in May.

Labidesthes sicculus Cope.-Brook silverside. 2 colls. 3 spms.

Two specimens were taken at Venedy Station and one 3 miles south of Carlyle. Length, 3 inches.

\section{LITERATURE CITED}

Buswell, A. M.

1927 Pollution of streams in Illinois.

Illinois State Water Survey Bulletin, No. 24. 33 pp. 1 fig., $21 \mathrm{pls}$.

COKER, Robert E.

1929 Studies of common fishes of the Mississippi river at Keokuk.

Bulletin of the United States Bureau of Fisheries, Vol. XLV, pp. 141-225. [Document No. 1072]. 30 figs.

COLE, LEON J.

1904 The German carp in the United States.

Report of the Bureau of Fisheries, pp. 523-641. 4 figs., 3 pls.

\section{EVERMANN, BARTON WARREN}

1899 Report on investigations by the United States fish commission in Mississippi, Louisiana, and Texas, in 1897.

Report of the Commissioner of the United States Commission of Fish and Fisheries, for the year ending June 30, 1898, pp. 285-310. pls. 8-36.

Evermann, Barton Warren, and H. Walton Clark

1920 Lake Maxinkuckee: a physical and biological survey.

Indiana State Department of Conservation, Vol. I. 660 pp. The fishes, pp. 238-451.

Forbes, Stephen Alfred, and Robert Earl Richardson

1909 The fishes of Illinois. 


\section{Literature Cited-Cont'd}

Natural History Survey of IllinoIs, State Laboratory of Natural History. cxxxi+357 pp. 76 figs., 55 pls. [2nd ed. 1920 , exxxvi +357 pp. 76 figs., 69 pls.]

GREeLEY, J. R.

1926 Fishes of the Genesee region with annotated list.

A Biological Survey of the Genesee River System-Supplemental to Sixteenth Annual Report, 1926, State of New York Conservation Department, Section IV, pp. 47-66. 9 pls.

1927 Fishes of the Oswego watershed.

A Biological Survey of the Oswego River System-Supplemental to Seventeenth Annual Report, 1927, State of New York Conservation Department, Section IV, pp. 84-107. 12 pls.

1928 Fishes of the Erie-Niagara watershed.

A Biological Survey of the Erie-Niagara System-Supplemental to Eighteenth Annual Report, 1928, State of New York Conservation Department, Section VI, pp. 150-179. 8 pls.

Hankinson, Thomas L.

1913 Distribution of fish in the streams about Charleston, Illinois.

Transactions of the Illinois State Academy of Science, Vol. VI, p. 102.1 fig.

1919 Notes on life-histories of Illinois fish.

Transactions of the Illinois State Academy of Science, Vol. XII, p. 132. 6 figs.

JORDAN, DAVID STARR

1929 Manual of the Vertebrate Animals of the Northeastern United States, Inclusive of Marine Species.

World Book Company, N. Y.

Jordan, David Starr, Barton Warren Evermann, and H. Walton Clark

1930 Check list of the fishes and fishlike vertebrates of North and Middle America north of the northern boundary of Venezuela and Colombia.

Report of the United States Commissioner of Fisheries for the fiscal year 1928, Part II. $670 \mathrm{pp}$.

PEARSE, A. S.

1918 The food of the shore fishes of certain Wisconsin lakes.

Bulletin of the United States Bureau of Fisheries, Vol. XXXV

(1915-1916), pp. 245-292.

Sette, Oscar E.

1925 Fisheries industries of the United States, 1923.

Report of the United States Commissioner of Fisheries for the fiscal year 1924, Appendix IV. $219 \mathrm{pp}$. [Bureau of Fisheries Document No. 976.] 


\section{Literature Cited-Concl'd}

Smallwood, W. M., and P. H. Struthers

1927 Carp control studies in Oneida lake.

A Biological Survey of the Oswego River System-Supplemental to Seventeenth Annual Report, 1927, State of New York Conservation Department, Section III, pp. 67-83. 5 figs.

Struthers, P. H.

1928 Carp control studies in the Erie canal.

A Biological Survey of the Erie-Niagara System-Supplemental to Eighteenth Annual Report, 1928, State of New York Conservation Department, Section X, pp. 208-219. 6 figs.

Thompson, David H., and Francis D. Hunt

1930 The fishes of Champaign county: a study of the distribution and abundance of fishes in small streams.

Illinois Natural History Survey Bulletin, Vol. XIX, Art. I, pp. 1-101. 6 figs., 52 maps.

Tracy, H. C.

1910 Annotated list of fishes known to inhabit the waters of Rhode Island.

Fortieth Annual Report of the Commissioners of Inland Fisheries [made to the General Assembly of the State of Rhode Island and Providence Plantations at its January Session, 1910]. pp. 35-176. 